\title{
Quality Assurance Project Plan for Facility Effluent Monitoring Plan Activities
}

\author{
T. P. Frazier
}

Date Published

October 1994

Prepared for the U.S. Department of Energy Office of Environmental Restoration and Waste Management

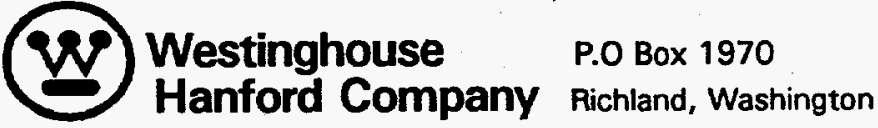

Hanford Operations and Engineering Contractor for the

U.S. Department of Energy under Contract DE-AC06-87RL10930

Approved for Public Release 


\section{DISCLAIMER}

This report was prepared as an account of work sponsored by an agency of the United States Government. Neither the United States Government nor any agency thereof, nor any of their employees, make any warranty, express or implied, or assumes any legal liability or responsibility for the accuracy, completeness, or usefulness of any information, apparatus, product, or process disclosed, or represents that its use would not infringe privately owned rights. Reference herein to any specific commercial product, process, or service by trade name, trademark, manufacturer, or otherwise does not necessarily constitute or imply its endorsement, recommendation, or favoring by the United States Government or any agency thereof. The views and opinions of authors expressed herein do not necessarily state or reflect those of the United States Government or any agency thereof. 


\section{DISCLAIMER}

Portions of this document may be illegible in electronic image products. Images are produced from the best available original document. 


\section{RELEASE AUTHORIZATION}

Document Number: WHC-EP-0446-2

Document Title: Quality Assurance Project Plan for Facility Effluent Monitoring Plan Activities

Release Date: $10 / 20 / 94$

This document was reviewed following the procedures described in WHC-CM-3-4 and is:

APPROVED FOR PUBLIC RELEASE

$* * * * * * * * * * *$

WHC Information Release Administration Specialist:

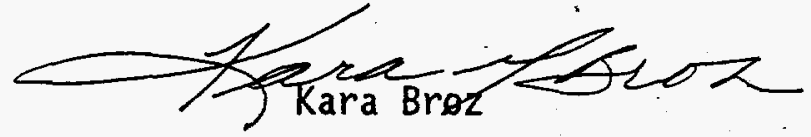

October 20, 1994

(Signature)

(Date) 
Document Title: Quality Assurance Project Plan for Facility Effluent Monitoring Plan Activities

Prepared by:

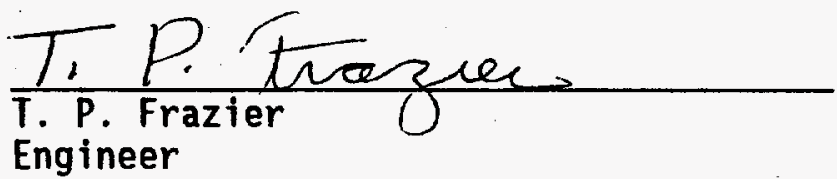<smiles>[R10]C(C)(C)C1CCCCC1</smiles>

Approved by:

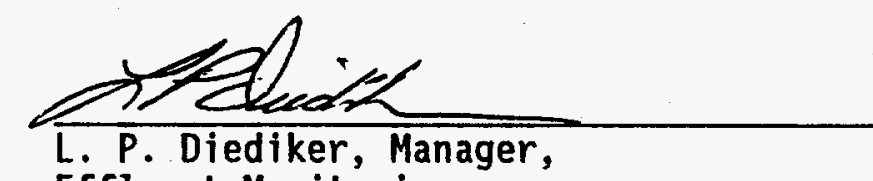

$\frac{9-15-94}{\text { Date }}$

Approved by:

\section{Effluent Monitoring}

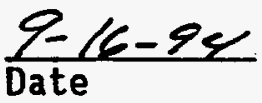

Approved by:

hul Varee For

D. D. Volkman, Manager, Engineering and $\frac{9-16-94}{\text { Date }}$ 


\section{QUALITY ASSURANCE PROJECT PLAN FOR FACILITY} EFFLUENT MONITORING PLAN ACTIVITIES

\section{ABSTRACT}

This Quality Assurance Project Plan addresses the quality assurance requirements for the activities associated with the Facility Effluent Monitoring Plans, which are part of the overall Hanford Site Environmental Protection Plan (DOE/Quality [RL 93-97] [DOE-RL 1993]). This plan specifically applies to the sampling and analysis activities and continuous monitoring performed for all Facility Effluent Monitoring Plan activities conducted by Westinghouse Hanford Company. It is generic in approach and will be implemented in conjunction with the specific requirements of the individual Facility Effluent Monitoring Plans.

U.S. Department of Energy Order 5400.1, General Environmental Protection Program (DOE 1988a) and DOE/RL-93-97, U.S. Department of Energy-Richl and Operations Office Environmental Protection Plan (DOE-RL 1993), requires U.S. Department of Energy sites to prepare and update Facility Effluent Monitoring Plans by November 9 of each year. To accomplish this task, Westinghouse Hanford Company has prepared a Facility Effluent Monitoring Plan guidance document (WHC-EP-0438-01, A Guide for Preparing Hanford Site Facility Effluent Monitoring Plans [WHC 1992a]) to be used by Hanford Site contractors in preparing Facility Effluent Monitoring Plan determinations and subsequent Facility Effluent Monitoring Plans. 


\section{WHC-EP-0446-2}

DOE Order 5700.6C, Quality Assurance (DOE 1991), DOE Order 5400.1 (DOE 1988a), and this Quality Assurance Project Plan address the appropriate requirements of DOE orders in compliance with the guidance of Interim Guidelines and Specifications for Preparing Quality Assurance Project. Plans, QAMS-005/80 (EPA 1983), and Quality Assurance Methods, 40 Code of Federal Regulations 61, Appendix B, Method 114 (EPA 1992b). The means selected to implement the overall Quality Assurance program requirements are defined by the Westinghouse Hanford Company's Quality Assurance Manual, WHC-CM-4-2 (WHC 1993d).

The implementing procedures, plans, and instructions are appropriate for the control of effluent monitoring plans requiring compliance with U.S. Department of Energy, U.S. Environmental Protection Agency, State, and local requirements. This Quality Assurance Project Plan contains a matrix of organizational responsibilities, procedural resources from facility or site manuals used in the Facility Effluent Monitoring Plans, and a list of the analytes of interest and analytical methods for each facility preparing a Facility Effluent Monitoring Plan.

Distribution and revision control of this plan will be in compliance with Quality Requirement 5.0, "Instructions Procedures," and 6.0, "Document Contro7" from WHC-CM-4-2 (WHC 1993d). 


\section{CONTENTS}

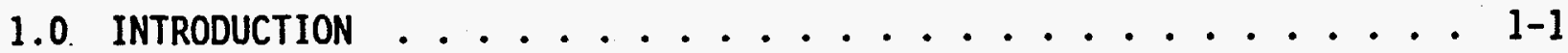

2.0 PROJECT DESCRIPTION . . . . . . . . . . . . . 2-1

2.1 GENERAL OBJECTIVES .................... 2-1

2.2 MONITORING ACTIVITIES DESCRIPTION .......... 2-1

2.3 APPLICABILITY TO WESTINGHOUSE HANFORD

COMPANY QUALITY ASSURANCE PROGRAM .......... 2-2

2.4 MINIMUM QUALITY ASSURANCE REQUIREMENTS FOR

FACILITY EFFLUENT MONITORING PLANS . . . . . . . . . 2-2

3.0 PROJECT ORGANIZATION AND RESPONSIBILITIES . . . . . . . . 3-1

3.1 PROJECT MANAGEMENT ......................... 3- . .

3.2 SUPPORTING ORGANIZATIONS ............... $3-3$

3.3 ANALYTICAL LABORATORIES .............. 3-5

3.4 OTHER SUPPORT CONTRACTORS ..................... 3-6

4.0 QUALITY ASSURANCE OBJECTIVES FOR MEASUREMENTS . . . . . . 4-1

4.1 ANALYTES OF INTEREST AND ANALYTICAL METHOD SELECTION . . . . 4-1

4.2 CONTRACTUAL QUANTITATION LIMITS AND RANGES FOR

ANALYTICAL PRECISION AND ACCURACY ........... 4-2

4.3 DOSE MODELING INPUT PARAMETERS .........

4.4 REPRESENTATIVENESS, COMPLETENESS, AND COMPARABILITY . . . 4-2

5.0 SAMPLING PROCEDURES ................ . . $5-1$

5.1 SAMPLING PROCEDURES $\ldots \ldots \ldots$...............

5.2 OTHER SUPPORTING PROCEDURES ........... 5-1

5.3 PROCEDURE APPROVALS AND CONTROL .......... $5-1$

5.3.1 Westinghouse Hanford Company Procedures ....... 5-1

5.3.2 Participant Contractor/Subcontractor Procedures . . . 5-1

5.4 PROCEDURE ADDITIONS AND CHANGES ........... 5-2

5.5 SAMPLING SCHEDULE ................. 5-2

6.0 SAMPLE CUSTODY ...................... 6-1

7.0 CALIBRATION PROCEDURES ..................

8.0 ANALYTICAL PROCEDURES . . . . . . . . . . . 8 8-1

9.0 MONITORING AND REPORTING CRITERIA . . . . . . . . . . . 9-1

10.0 DATA REDUCTION, VALIDATION, AND REPORTING ......... . 10-1

10.1 DATA REDUCTION AND DATA PACKAGE PREPARATION ....... 10-1

10.1.1 Gaseous Effluent Release Determinations . . . . . . 10-1 10.1.2 Liquid Effluent Release Determinations . . . . . 10-1

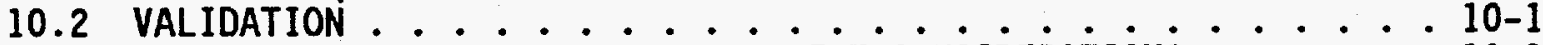

10.3 FINAL REVIEW AND RECORDS MANAGEMENT CONSIDERATIONS $\ldots \ldots 10-3$

11.0 INTERNAL QUALITY CONTROL ....................... . . .

12.0 SYSTEM AUDITS . . . . . . . . . . . . . . . 12-1 
WHC-EP-0446-2

CONTENTS (Continued)

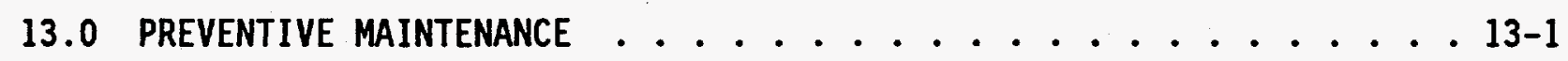

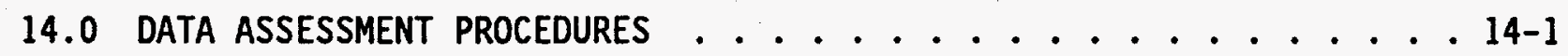

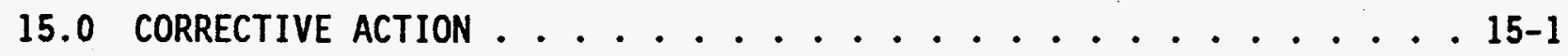

16.0 QUALITY ASSURANCE REPORTS . . . . . . . . . . . . 16-1

17.0 HUMAN FACTORS . . . . . . . . . . . . . . 17-1

17.1 EFFECTS OF HUMAN FACTORS

17.2 EFFECTS OF HUMAN FACTORS MINIMIZED BY

PROCEDURES AND QUALITY ASSURANCE PLANS .......... . . 17-1

18.0 GLOSSARY ............................ 18-1

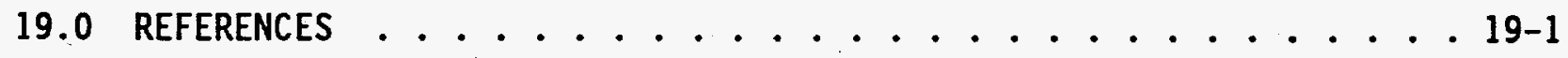

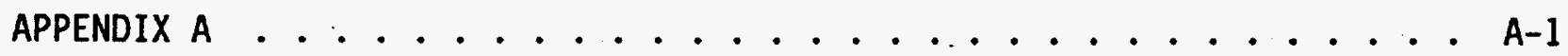

\section{LIST OF FIGURES}

3-1 Project Organizational Chart for FEMP Activities . . . . . . 3-2

\section{LIST OF TABLES}

3-1 Organizational Responsibilities Matrix for Effluent Sampling and Monitoring Program ............... . . 3-4

8-1 Analytical Procedures for FEMP Activities .......... 8-1 


\section{LIST OF TERMS}

AEA

CAS

CBRCS

CERCLA

CFR

CQL

DNFSB

DOE

DOE-RL

DOE-HQ

ECN

Ecology

EDE

EES

EIS

EM

EMP

EPA

ES

FEMP

LES

NESHAP

NPDES

PFP

PEIS

PNL

PUREX

POC

QA

QAMS

QAPjP

QC

QI

QR

$\mathrm{RL}$

RCRA

ROD

RWP

SAP

SNF

SNFP

TQO

WHC
Alpha Energy Analysis

Commercial Analytical Services

Component-Based Recall Calibration System

Comprehensive Environmental Response, Compensation and Liability Act of 1980

Code of Federal Regulations

Contractual Quantitation Limit

Defense Nuclear Facilities Safety Board

U.S. Department of Energy

U.S. Department of Energy-Richland Operations Office

U.S. Department of Energy-Headquarters

Engineering Change Notice

Washington State Department of Ecology

Effective Dose Equivalent

Environmental Engineering Studies

Environmental Restoration Program

Effluent Monitoring

Environmental Monitoring Plan

U.S. Environmental Protection Agency

Environmental Services

Facility Effluent Monitoring Plan

Liquid Effluent Study

National Emission Standards for Hazardous Air

Pollutants

National Pollution Discharge Elimination System

Plutonium-Finishing Plant

Programmatic Environmental Impact Statement

Pacific Northwest Laboratory

Plutonium-Uranium Extraction (Facility at Hanford

Site

Point-of-Contact

Quality Assurance

Qual ity Assurance Methods

Quality Assurance Project Plan

Quality Control

Quality Instruction

Qual ity Requirement

U.S. Department of Energy Richland, Operations Office

Resource Conservation and Recovery Act of 1976

Record of Decision

Radiation Work Permit

Sampling Analysis Plan

Spent Nuclear Fuel

Spent Nuclear Fuel Plan

Technical and Quality Oversight

Westinghouse Hanford Company 


\section{WHC-EP-0446-2}

This page intentionally left blank. 
WHC-EP-0446-2

\section{QUALITY ASSURANCE PROJECT PLAN FOR FACILITY EFFLUENT MONITORING PLAN ACTIVITIES}

\subsection{INTRODUCTION}

U.S. Department of Energy (DOE) Order 5400.1, General Environmental Protection Program (DOE 1988a), required DOE sites to prepare an Environmental Monitoring Plan (EMP) by November 9, 1991.

According to the guidance provided in DOE Order 5400.1 (DOE 1988a), each DOE site, facility, or activity that uses, generates, releases, or manages significant quantities of hazardous materials shall provide a written EMP. This EMP must identify and discuss two major activities: (1) effluent monitoring, and (2) environmental surveillance.

At the Hanford Site, the site-wide EMP (DOE/RL 93-97 [DOE-RL 1993]) contains the following elements:

- A conceptual plan addressing effluent monitoring and environmental surveillance

- A listing of contractor facility effluent monitoring plans (FEMP)

- Two distinct operational EMPs describing Westinghouse Hanford Company (WHC) near-facility and Pacific Northwest Laboratory (PNL) site-wide environmental surveillance activities.

To address the second item above and to fulfill the requirements of the United States Department of Energy-Richland Operations Office Environmental Protection Implementation Plan, DOE/RL 89-18 (DOE-RL 1989), the WHC Effluent Monitoring (EM) function has prepared a FEMP guidance document (WHC 1992a) to be used by the Hanford Site contractors in preparing FEMP determinations and FEMPs.

Every major WHC-managed facility prepared a FEMP determination (which dictates where FEMPs are actually needed) in accordance with the guidance document, and FEMPs have been prepared and issued where required. New or modified facilities requiring FEMPs must have a FEMP determination and/or a FEMP completed before startup.

This Quality Assurance Project Plan (QAPjP) addresses quality assurance (QA) implementation of WHC FEMPs. Section 12.0 of each individual FEMP addresses facility-specific QA requirements and refers to this QAPJP for the general $Q A$ requirements. 
WHC-EP-0446-2

This page intentionally left blank. 
WHC-EP-0446-2

\subsection{PROJECT DESCRIPTION}

\subsection{GENERAL OBJECTIVES}

The general objectives of the FEMP are as follows:

- Ensure compliance with DOE Orders 5400.1 (DOE 1988a), 5400.3 (DOE 1989b), 5400.4 (DOE 1989a), 5400.5 (DOE 1990), 5480.1 (DOE 1982), 5480.1 (DOE 1988b), 5484.1 (DOE 1981), and 5700.6C (DOE 1991)

- Ensure that facility effluent monitoring systems provide an adequate means of determining releases to the environs to assess the impact of these releases on the public and the environment

- Ensure that facility operations are in compliance with applicable Federal, State, and local emission standards and requirements.

Briefly summarized, FEMPs require characterization of radioactive and nonradioactive gaseous and liquid effluents from all WHC facilities or sites, and detection of statistically significant concentrations of specified contaminants in these effluents. In addition, assessment of compliance with the U.S. Environmental Protection Agency (EPA) "National Emission Standards for Hazardous Air Pollutants" (NESHAP) (40 Code of Federal Regulations [CFR] 61, Subpart H) (EPA 1992a) for radioactive airborne effluents shall be included in FEMP determinations and subsequent FEMPs. Facility-specific procedures shall be referenced in the. FEMPs to demonstrate compliance. The QAPJP for the FEMPs sha11 address the QA requirements in DOE Order 5700.6C (DOE 1991).

\subsection{MONITORING ACTIVITIES DESCRIPTION}

The specific effluent monitoring activities performed by WHC are defined by applicable FEMPs as required in DOE Order 5400.1 (DOE 1988a) and generally fall into one or both of the categories described below.

- Sampling of facility effluent streams: This category includes all routine environmental 7 iquid and gaseous sampling collection, radiological analysis, and chemical analysis, together with data validation and data analysis associated with facility effluent streams. In-process sampling is not included in the FEMP because it is not considered an effluent by definition. Also, Resource Conservation and Recovery Act of 1976 (RCRA) protocol liquid effluent sampling, associated with the 1iquid effluent study (LES), is not included in the FEMP. However, sample results obtained for this study, because they are controlled by the strict QA requirements from the Test Method for Evaluating Solid Waste, SW-846-1 (EPA 1992C) as suggested by 40 CFR 246, Appendix IX complement the routine environmental monitoring program. The LES program also provides an analysis of the norad constituents in the waste streams that are not covered by any routine environmental monitoring sampling programs. A QA program plan, WHC-EP-0536-1, 
Quality Assurance Program PJan for Radionuclide Airborne Emissions Monitoring (WHC 1993e), has been prepared to define the QA requirements of 40 CFR 61 , Appendix B, Method 114, and Subpart H(EPA 1992b).

- Monitoring and recording of facility effluent streams: This category includes establishing appropriate alarm/diversion set points, documenting process upsets or out-of-compliance conditions, and maintaining a record of maintenance calibrations and operability test results on the effluent monitors (i.e., continuous monitors).

\subsection{APPLICABILITY TO WESTINGHOUSE HANFORD COMPANY QUALITY ASSURANCE PROGRAM}

This QAPjP applies specifically to the sampling and analysis activities and continuous monitoring performed for all FEMP activities conducted by WHC. This QAPjP is generic in approach and shall be implemented in conjunction with the specific requirements of individual FEMPs.

The QAPJP is prepared in compliance with Interim Guidelines and Specifications for Preparing Quality Assurance Project Plans, QAMS-005/80 (EPA 1983), and "Quality Assurance Methods," 40 CFR 61, Appendix B, Method 114 (EPA 1992b). It describes the means selected to implement the appropriate QA program requirements found in the Quality Assurance Manual, WHC-CM-4-2 (WHC 1993d). The QAPJP contains a matrix of procedural resources from facility or site manuals used in the FEMPs. This QAPJP shall be reviewed and updated as required by changes made in the FEMP activities. Distribution and revision control of this plan shall be in compliance with quality requirement (QR) 5.0, "Instructions Procedures," and 6.0 "Document Control" from WHC-CM-4-2 (WHC 1993d). The QAPjP distribution shall routinely include all review and approval personnel indicated on the title page of the document and all other individuals designated by WHC's Environmental Services function. Plans and procedures referenced in the QAPJP are available for regulatory review on request.

\subsection{MINIMUM QUALITY ASSURANCE REQUIREMENTS FOR FACILITY EFFLUENT MONITORING PLANS}

The FEMP prepared for each individual facility should consider the requirements of this QAPJP and select the necessary procedural controls from the generic requirements of this plan that are specifically applicable to individual effluent sampling and monitoring activities. All applicable DOE Order 5700.6C (DOE 1991) requirements shall be included within this QAPJP or addressed in Section 12.0 of the FEMPs. At a minimum, the FEMP should address the items below:

- Establishment of analytes of interest and specific objectives for data quality. These items are defined in the following documents:

Internal memo 88420-93-135b, dated December 21, 1993, from Effluent and Emission Monitoring, Analytical Requirements for FY-94 Liquid Effluent and Air Emission Samples, (Diediker 1993). 
PNL-MA-597, Analytical Chemistry Laboratory Manual (PNL 1991a)

K-Basin Process Standard \# D-403 (WHC 1991a)

Battelle Memorial Institute Pacific Northwest Laboratory

Contract No. 163587-A-M1 (PNL 1993)

FFTF Operations Operating Procedure

SN-23.13-3, Operation of Process Sewer (WHC 1994a)

WHC-SD-L045H-PLN-001, Rev 0, "300 Area Process Sewer Sampling Analysis Plan" (WHC 1993a)

Statement of Work for Services Provided by Pacific Northwest Laboratory's Analytical Chemistry Laboratory for the 340 Facility (Perry 1993)

Internal memo 9359235; dated November 15, 1992, from FFTF Regulatory Compliance, Letter of Instruction--Work Order ED4232 (Seamens 1993)

PNA-MA-70. Quality Assurance (QA) Program (PNL 1991b)

MSC-033, Analytical Chemistry Laboratory (ALC) QA P1an (PNL 1991c)

The FEMPS should define the analytical parameters and reference methods applicable to specific sampling. If modifications to contractually established detection limits, precision, and accuracy values are required, they should be specifically noted in the text of the FEMP.

- Establishment of specific procedural controls. Based on the comprehensive list provided in Table $A-1$, individual FEMPs should define specific procedural controls that apply to the individual facilities.

- Establishment of unique procedural additions, optional methodologies, modifications, and controls. Where optional and/or a) ternative methodologies are included in procedures, the options most appropriate for particular facilities are to be specified in the FEMP. Additional procedures or special-case procedural modifications should be defined and appended or included by reference as appropriate.

- Establishment of facility-specific performance or system audit requirements. Performance or system audit requirements over and above scheduled audits performed by appropriate organizations (i.e., QA and Environmental Compliance Assurance) shall be defined. 
WHC-EP-0446-2

This page intentionally left blank. 
WHC-EP-0446-2

\subsection{PROJECT ORGANIZATION AND RESPONSIBILITIES}

\subsection{PROJECT MANAGEMENT}

WHC's Environmental Services function has the primary responsibility to verify that the responsible line organization has specified the requirements for effluent monitoring. The ES function also has the responsibility to provide guidance in FEMP preparation. An organizational chart is included as Figure 3-1. Responsibilities of key personnel are described below.

- Environmental Services/Effluent Monitoring. The EM group within ES has the responsibility to oversee and verify the environmental radioactivity and chemical emission monitoring program at WHC facilities as required to ensure compliance to environmental regulations.

The EM group acts as the technical liaison between the facilities' management and the Regulatory Analys is group on issues pertaining to the effluent monitoring program, and provides guidance for implementing that program. The EM group also provides technical support for effluent sampling and analysis, and prepares annual emissions reports to DOE and the appropriate regulatory agencies. The EM group is responsible for assigning the unique electronic data processing codes and identification numbers for each sample point at each facility. The EM group maintains permanent records of radioactive effluent releases discharged from each WHC facility. The EM QA requirements for compiling and reporting radioactive airborne emissions data are contained in the Quality Assurance Project PIan for Radioactive Airborne Emissions Data Compilation and Reporting, WHC-EP-0528-1 (WHC 1994b). EM uses the environmental release summary database to contain radioactive emissions data used for annual reports.

- Facility Effluent Monitoring Plan Coordinator. The FEMP program coordinator for ES coordinates technical activities for the effluent monitoring program. The coordinator is responsible to ensure that all effluent monitoring program elements (planning, organizing, scheduling, and ensuring quality reviews) are performed. This coordinator is an assigned representative in the EM group, and provides technical guidance to individual facility cognizant engineers, facility sampling and analys is task leaders, and designated FEMP authors.

- Environmental Compliance Officer(s). The Environmental Compliance Officer (ECO) is an individual designated to be the facility or department point-of-contact for (POC) environmental issues. The ECO is to provide support to the facility or department manager to ensure compliance with the applicable environmental compliance requirements as identified in WHC-CM-7-5 (WHC 1993b), environmental permits, the Hanford Federal Facility Agreement and Consent Order and other compliance orders. Ensure that the facility or department 


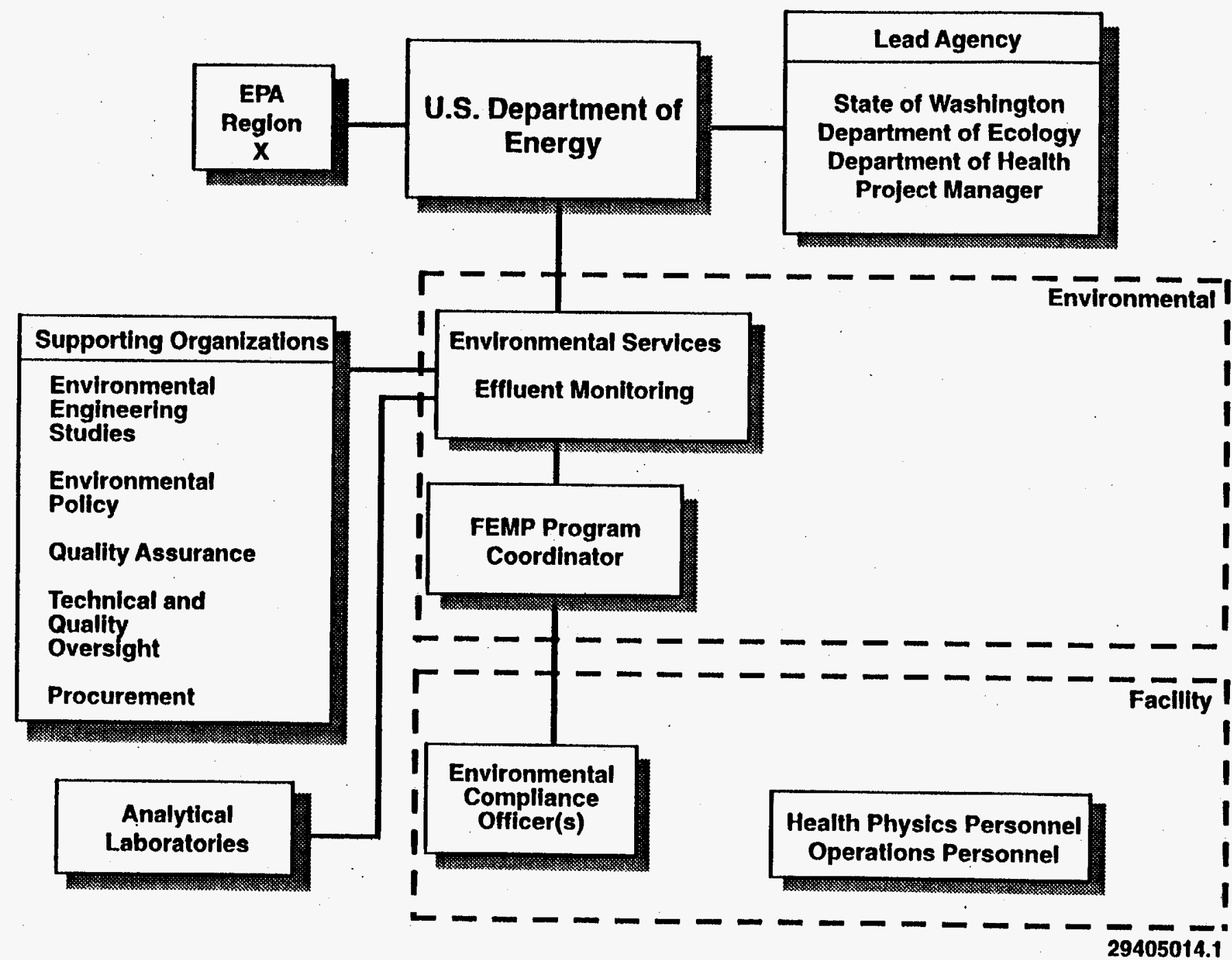


WHC-EP-0446-2

manager is aware of the facility's environmental compliance status and the facility's environmental compliance activities. Understand and be able to explain the facility's or department's environmental compliance status with all applicable environmental requirements. Advise the facility or department manager of new environmental requirements and policies, the associated impacts and recommended implementation mechanisms to ensure compliance.

\subsection{SUPPORTING ORGANIZATIONS}

Routine technical support to ES will be provided through several WHC organizations as described below.

- Quality Assurance. QA provides quality engineering support related to procurement control, document approval, surveiliance, and auditing needs.

- Environmental Engineering Studies. The Environmental Engineering Studies (EES) group within ES has the responsibility to plan, direct, and execute the near-facility operational environmental monitoring program for all media except groundwater, and to ensure that the requirements of this program are implemented. In addition, this group acts as the primary interfacing organization for environmental adverse condition statements and for tracking operational environmental monitoring and compliance assessment inspections. The EES QA requirements for the Operational Environmental Monitoring Program are contained in WHC-EP-0538, Operational Environmental Monitoring Program Quality Assurance Project Plan (WHC 1992C).

- Procurement. The procurement organization obtains services and/or contracts in accordance with purchase requisitions, purchase orders, drawings, contracts, specifications, or instructions used to define requirements for a purchase.

- Health Physics/Operations Personnel. These personnel provide sampling and monitoring support as defined in the FEMPs. Usually, Health Physics is the organization that collects the airborne samples for the facility. Operations personnel typically collect the liquid samples in each facility.

- Environmental Policy. These personnel provide guidance in interpretation of all regulations and interface with the regulatory agencies pertaining to such matters.

Table 3-1 summarizes the organizational responsibilities. 
Table 3-1. Organizational Responsibilities Matrix for Effluent Sampling and Monitoring Program. (2 sheets)

\begin{tabular}{|c|c|c|c|c|c|c|c|}
\hline \multicolumn{2}{|r|}{ Task } & EM & $Q A$ & FO & TQO & LABS & $H P$ \\
\hline 1 & $\begin{array}{l}\text { Prepare FEMPs and FEMP } \\
\text { Determinations }\end{array}$ & R & $\mathbf{R}$ & A & & & \\
\hline 2 & Prepare FEMPS Revisions & $R$ & & A & & & \\
\hline 2 & $\begin{array}{l}\text { Prepare Facility-Specific } \\
\text { Implementing Procedures }\end{array}$ & $\mathbf{R}$ & $\mathbf{R}$ & A & & & \\
\hline 3 & Take Effluent Samples & $v$ & & A & & & A \\
\hline 4 & Prepare Spiked Samples & & & & & A & \\
\hline 5 & Ship Samples & & & A & & & \\
\hline 6 & Track Samples & & & $\mathbf{R}$ & & A & \\
\hline 7 & $\begin{array}{l}\text { Review/Approve Procedure } \\
\text { for Offsite Laboratories }\end{array}$ & $\mathrm{R}$ & & A & & & \\
\hline 8 & $\begin{array}{l}\text { Review/Approve Services } \\
\text { Provided by 222-S } \\
\text { Laboratory. }\end{array}$ & A & $\mathrm{R}$ & $\mathbf{R}$ & & & \\
\hline 9 & Analyze Samples & & & & & A & \\
\hline 10 & Audit Laboratory $Q A / Q C$ & & A & & & & \\
\hline 11 & $\begin{array}{l}\text { Receive Laboratory Test } \\
\text { Reports and Transmit to } \\
\text { Facility }\end{array}$ & A & & & & & \\
\hline 12 & Review and Validate Data & A & & & A & & \\
\hline 13 & $\begin{array}{l}\text { Conduct Final Technical } \\
\text { Review of Validation } \\
\text { Reports and Supporting } \\
\text { Analytical Data Packages }\end{array}$ & $\mathrm{R}$ & & & A & & \\
\hline 14 & $\begin{array}{l}\text { Compare Test Results To } \\
\text { Operating Limits }\end{array}$ & v & & A & & & \\
\hline
\end{tabular}


Table 3-1. Organizational Responsibilities Matrix for Effluent Sampling and Monitoring Program. (2 sheets)

\begin{tabular}{|c|l|c|c|c|c|c|c|}
\hline \multicolumn{2}{|c|}{ Task } & EM & QA & FO & TQO & LABS & HP \\
\hline 15 & $\begin{array}{l}\text { Prepare Environmental } \\
\text { Release Reports, NESHAP and } \\
\text { NPDES Reports, etc. }\end{array}$ & A & & R & & & \\
\hline 16 & $\begin{array}{l}\text { Programmatic Audits and } \\
\text { Surveillances }\end{array}$ & & $\mathrm{A}$ & & & & \\
\hline
\end{tabular}

Legend:

$$
\begin{aligned}
A & =\text { Action } \\
E C A & =\text { Environmental Compliance Assurance } \\
E M & =\text { Emission Monitoring } \\
\text { FEMP } & =\text { Facility Effluent Monitoring Plan } \\
F O & =\text { Facility Operations } \\
H P & =\text { Health Physics } \\
\text { NESHAP } & =\text { National Emission Standards for Hazardous Air Pollutants } \\
\text { NPDES } & =\text { National Pollution Discharge El imination System } \\
Q A & =\text { Quality Assurance } \\
Q C & =\text { Quality Control } \\
R & =\text { Review and Approve } \\
\text { SOW } & =\text { Statement of Work } \\
\text { TQO } & =\text { Technical and Qual ity Oversight } \\
V & =\text { Validation and/or Verification }
\end{aligned}
$$

*NOTE: The review and validation process varies from facility to facility and is specifically described in each FEMP.

\subsection{ANALYTICAL LABORATORIES}

Analytical samples will be transported to an approved WHC participant contractor or subcontractor laboratory for radiological and/or chemical analysis. For participant contractors or subcontractors, applicable Quality Requirements of this QAPjP shall be invoked as part of the approved applicable work order or procurement document. Off-site laboratories are to submit their analytical methods and internal QA program plan for WHC review and approval before use.

The 222-S Laboratory on the Hanford Site has one program $\mathrm{plan}$ and one project plan to address applicable Quality Requirements related to sample analysis. These plans are as follows:

- WHC-SD-CP-QAPP-003-1A, Quality Assurance Program P7an for Laboratory Analysis and Process Testing (WHC 1994C)

- WHC-SD-CP-QAPP-002, Quality Assurance Project Plan for the Chemical Analysis of Highly Radioactive Mixed Waste Samples in Support of Environmental Activities on the Hanford Site (WHC 1993f). 


\subsection{OTHER SUPPORT CONTRACTORS}

Procurement of the services of other subcontractors (PNL, IT) to support any or all of the activities addressed by this QAPjP may be initiated at the direction of ES and PNL. Such services shall be in compliance with standard WHC procurement procedures requirements. All work shall be reviewed for compliance with WHC-approved QA plans and/or procedures. 
WHC-EP-0446-2

\subsection{QUALITY ASSURANCE OBJECTIVES FOR MEASUREMENTS}

The QA objectives for measurements generally applicable to FEMPs under the purview of this QAPJP primarily are related to the following:

- Defining appropriate methods for sampling and chemical analysis for required analytes of interest

- Defining quantitation limits and values for analytical precision and accuracy appropriate for all facility effluent monitoring at the Hanford Site

- Defining data representativeness, completeness, and comparability in terms applicable to Hanford Site FEMPs.

Detailed discussions of the analytes of interest are provided in Internal Memo 88420-93-135b titled: "Analytical Requirements for FY-94 Liquid Effluent and Air Emission Samples" (Diediker 1993) for 200 Area facilities and in the statements of work, sample analysis plans, or facility-specific procedures for the 100, 300, and 400 Areas. The detailed discussion of the analytical methods is found in Table 8-1 of this document, Table 5-1 of WHC-EP-0528 and the statements of work or sample analysis plans, or facility-specific procedures for the 100,300, and 400 Areas (see Section 2-4). For individual investigations that are over and above the minimum requirements established herein, specific data quality needs shall be addressed within individual FEMPs. Other measurement considerations, accuracy requirements, units, and data recording and reporting protocols for instruments supporting effluent monitoring and other types of field facility effluent monitoring investigations shall be specified in the applicable procedures discussed herein and listed in Table A-1.

\subsection{ANALYTES OF INTEREST AND ANALYTICAL METHOD SELECTION}

The Internal Memo 88420-93-135b titled: "Analytical Requirements for FY-94 Liquid Effluent and Air Emission Samples" (Diediker 1993) and Services Provided by the 222-S Laboratory for Regulatory Support, WHC-EP-0689 (Thomas 1993) identify the analytes of interest based on input from the individual FEMPs and the corresponding analytical reference methods for effluent sampling and monitoring at the 200 Area facilities. The statements of work or sample analysis plans or facility-specific procedures written for the 100,300 , and 400 Areas identify the analytes of interest and the corresponding analytical reference methods (see Section 2-4). 


$$
\text { WHC-EP-0446-2 }
$$

\subsection{CONTRACTUAL QUANTITATION LIMITS AND RANGES FOR ANALYTICAL PRECISION AND ACCURACY}

The performance of the analytical 1aboratory or laboratories providing support to effluent sampling and monitoring shall be subject to EPAestablished method- and analyte-specific quantitation limits and ranges for precision and accuracy (EPA 1972, EPA 1977) in accordance with the approved statement of work.

\subsection{DOSE MODELING INPUT PARAMETERS}

Dose limits to the public from airborne effluents dictate airborne effluent monitoring requirements. The EPA radioactive airborne criteria (NESHAPS, 40 CFR 61) (EPA 1992a) require that radionuclide emissions from each DOE site do not cause any individual (maximally exposed member of the public) to receive a dose greater than $10 \mathrm{mrem} / \mathrm{yr}$ effective dose equivalent (EDE).

To demonstrate compliance with the dose 1 imit requirements using analytical techniques, evaluations of potential doses to individuals shall be evaluated using approved EPA computer codes or models as specified in the NESHAPS, 40 CFR 61 (EPA 1992a). Input parameters are obtained from historical data, PNL sitewide environmental surveillance reports, and Hanford Site meteorological data. The results of the dose models are included in the FEMP determinations and annual Air Emissions Report to EPA for each calendar year. (They are not included in Table $A-1$. ) At the effluent points where the dose i imits ( $0.1 \mathrm{mrem} / \mathrm{yr}$ EPA, WHC administrative control values) could be exceeded, monitoring shall be performed in accordance with the procedures identified in Table A-1 and the FEMPs.

\subsection{REPRESENTATIVENESS, COMPLETENESS, AND COMPARABILITY}

Data representativeness, completeness, and comparability are addressed qual itatively within the applicable FEMP. Concerted efforts are made to ensure that samples collected are representative of the condition being analyzed. For completeness of chemical analyses, the goal is to produce useable analytical data for a minimum of 90 percent of the analyses requested on all samples submitted to the 222-S Laboratory or other subcontractor laboratory. The laboratory's actual performance is evaluated against the 90percent objective, and failure to meet this criterion shall be documented in data summary reports and shall be considered in the validation process. Corrective action measures using specified procedures shall be initiated by the EM, CAS, TQO, or QA, as appropriate. To facilitate the comparability of data sets in terms of precision and accuracy, approved analytical procedures shal1 require the use of reporting techniques and units consistent with the EPA reference methods and WHC-SD-CP-QAPP-003-1A, Quality Assurance Program Plan for Laboratory Analyses and Process Testing (WHC 1994C).

The 222-S Laboratory participates in the EPA intercomparison program in which blind samples are provided by the EPA and analyzed by the laboratory. 
WHC-EP-0446-2

\subsection{SAMPLING PROCEDURES}

\subsection{SAMPLING PROCEDURES}

To ensure that samples are transported only to laboratories that are appropriately equipped and licensed for receiving radioactive materials and performing mixed waste analyses, sampling activities and equipment and sample material and containers will be subjected to field screening (radiological survey and quality control [QC] check of transporting documentation) for radioactivity in compliance with the requirements of governing radiation work permits (RWP). All effluent sampling in support of the FEMPs will be performed in a manner that provides representative measurements of the volume and concentration of airborne and liquid pollutants released to the environment, as well as the total volume released (gallons, cubic feet).

\subsection{OTHER SUPPORTING PROCEDURES}

Except for the analytical chemistry procedures specified in Table 8-1, Internal Memo 88420-93-135b (Diediker 1993) and statements of work written for the 100,300, and 400 Areas, procedures that directly support FEMP activities are presented in Table A-1. These procedures are cross referenced to their source documents and the types of activities they will support. Any additions or modifications to procedures listed here shall be addressed in the individual FEMPs.

\subsection{PROCEDURE APPROVALS AND CONTROL}

\subsubsection{Westinghouse Hanford Company Procedures}

The WHC procedures that may be used to support the sampling and monitoring activities specifically defined by individual FEMPs are referenced in Table A-1. Latest approved versions of all referenced procedures shall apply in all cases. Selected procedures include QR and QI from WHC-CM-4-2, Quality Assurance Manual (WHC 1993d), and plant operating manuals. Procedure approval, revision, and distribution control requirements applicable to QI and $Q R$ are addressed in QR 5.0, "Instructions Procedures" and 6.0, "Document Control" (WHC 1993d). All procedures are available for regulatory review on request at the direction of ES. Other applicable WHC procedures may be facility specific and are defined in the individual FEMPs.

\subsubsection{Participant Contractor/Subcontractor Procedures}

All procedures used by participant contractor/subcontractor shall be reviewed and approved. Such requirements shall be included in the procurement document or work order. In addition to submitting analytical procedures, analytical laboratories shall be required to submit the current version of their internal QA program plans to be reviewed and approved. All participant contractor or subcontractor procedures, QA plans, and/or manuals should be retained as project quality records in compliance with WHC-approved procedure QR 17.0, 
"Qual ity Assurance Records" and QI 17.1, "Quality Assurance Records Control" (WHC 1993d). All such documents should be made available for regulatory review on request, at the direction of $E S$.

\subsection{PROCEDURE ADDITIONS AND CHANGES}

Additional procedures, or changes to existing procedures found necessary as a consequence of individual FEMP requirements, shall be developed in accordance with Management Requirements and Procedures, WHC-CM-1-3, 2.16 (WHC 1994f) and WHC-CM-4-2, QRs 5.0 and 6.0 (WHC 1993d). Should deviations from estabi ished procedures be required to accommodate unforeseen field situations, they may be authorized in accordance with the requirements of an appropriate facility-specific procedure. Documentation, review, and disposition of instruction change authorization forms shall be defined within the facilities' plant administrative procedures. Other types of document change requests shall be completed as Engineering Change Notices (ECN) in accordance with EP 2.2 "Engineering Document Change Control," WHC-CM-6-1, Standard Engineering Practices (WHC 1993g). Should facility-specific procedural changes or deviations be necessary, they shall be performed according to the facility-specific internal procedures.

\subsection{SAMPLING SCHEDULE}

Record sampling should be the sampling method for FEMP activities. By definition, a record sample is a representative sample collected in an air and liquid sampling system for laboratory analysis. Record samples are used as a basis for reporting to DOE, facility operation, and safety the amounts of contaminants released to the environment.

A11 record sampling schedules are approved by EM. Any changes to the radioactive gaseous effluent record sampling schedule or the liquid effluent record sampling schedule, including temporary or one-time deviations, shall be preapproved by EM in accordance with the Environmental Compliance Manual WHC-CM-7-5 (WHC 1993b). 


\subsection{SAMPLE CUSTODY}

All samples obtained during FEMP activities shall be controlled as required by an approved facility sample control procedure for air samples, such as the Health Physics Procedures Manual, WHC-IP-0718 (WHC 1993c) or facility-created chain-of-custody procedures for handling liquid effluent monitoring samples. The facility procedure applies as soon as sample is introduced to the sample container in which it will be preserved, sealed, labeled, and transported to the analytical laboratory. Laboratory chain-ofcustody procedures shall be established. These procedures shall ensure maintenance of sample integrity and identification from receipt through completion of the analytical process. Requirements for returning residual sample materials after analys is is complete shall be defined in the procurement documentation or work orders to subcontractor or participant contractor laboratories. Chain-of-custody forms shall be signed out for returned original samples as required by the approved procedures applicable within the participating laboratory. Analyses results shall be traceable to original samples through unique sample numbers or identification codes. All analyses results shall be controlled as permanent project quality records, as required by QR 17.0, "Quality Assurance Records" (WHC 1993d), and Document Control and Records Management, WHC-CM-3-5 (WHC 1994d), or equivalent WHCapproved procedure. 
WHC-EP-0446-2

This page intentionally left blank. 


\subsection{CALIBRATION PROCEDURES}

Calibration and maintenance are the controlling factors in this system. Calibration of all WHC measuring and test equipment, whether in the existing inventory or purchased for effluent sampling and monitoring, shall be controlled as required by $Q R$ 12.0, "Control of Instrument". Routine operational checks for WHC field equipment shall be as defined in applicable facility-specific internal procedures; similar information shall be provided within WHC-approved participant contractor or subcontractor procedures. The sampling and monitoring equipment used in this activity is controlled by the Component-Based Recall Calibration System (CBRCS) or another WHC-approved system.

Calibration procedures/requirements for offsite laboratories are addressed in the procurement or statement of work documents. Calibration procedures can be made available on request at the direction of the ES. manager. 
WHC-EP-0446-2

This page intentionally left blank. 


\subsection{ANALYTICAL PROCEDURES}

Analytical methods or procedures based on the reference methods for radioactive airborne emissions are identified in WHC-EP-0528-1 (WHC 1994b) Table 5-1. While analytical methods or procedures for liquid effluents are identified in Table 8-1 below shall be selected or developed and approved before use, in compliance with appropriate WHC procedure, work order, and/or procurement control requirements (Section 4.2). The following table summarizes the analytical procedures used for the WHC facility laboratories. Procedures from other offsite laboratories performing analyses on environmental samples are not provided in this section.

Table 8-1. Analytical Procedures for FEMP Activities.

\begin{tabular}{|c|c|}
\hline Procedure Number* & Title \\
\hline LA-613-111 & $\begin{array}{l}\text { Determination of }{ }^{147} \mathrm{Pm} \text { in Effluent Water } \\
\text { Samples by Solvent Extraction and Liquid } \\
\text { Scintillation Counting }\end{array}$ \\
\hline LA-925-008 & $\begin{array}{l}\text { Uranium by Laser Induced Kinetic } \\
\text { Phosphorescence. }\end{array}$ \\
\hline LA-220-103 & $\begin{array}{l}{ }^{90} \mathrm{Sr}{ }^{89} \mathrm{Sr},{ }^{90} \mathrm{Sr} \text { and } / 0 \mathrm{r}{ }^{89} /{ }^{90} \mathrm{SR} \text { from Leachated } \\
\text { of Soil, Vegetation, Air Filters and Other } \\
\text { Sol id Samples }\end{array}$ \\
\hline LA-548-121 & $\begin{array}{l}{ }^{60} \mathrm{Co} \text { Preparation of Sample Mounts for Gamma } \\
\text { Energy Analysis }\end{array}$ \\
\hline LA-943-123 & $\begin{array}{l}\mathrm{Pu}{ }^{239},{ }^{240} \mathrm{Pu},{ }^{241} \mathrm{Am} \text {, Separation of Plutonium and } \\
\text { Americium by Ion Exchange }\end{array}$ \\
\hline LA-378-101 & $\begin{array}{l}129 \text { I by Liquid - Liquid Extraction and Gamma } \\
\text { Energy Samples }\end{array}$ \\
\hline LA-220-104 & $\begin{array}{l}\text { Strontium- }{ }^{89} / 90 \mathrm{Sr} \text { and/or }{ }^{89} \mathrm{Sr} \text { and }{ }^{90} \mathrm{Sr} \text { in } \\
\text { Water by Carbonate Precipitation. }\end{array}$ \\
\hline LA-218-111 & $\begin{array}{l}\text { Tritium Analysis by Liquid Scintillation } \\
\text { Counting. }\end{array}$ \\
\hline LA-348-104 & $\begin{array}{l}{ }^{14} \mathrm{C} \text { in Small Volume Samples by Persulfate } \\
\text { oxidation and Liquid-Scintillation Counting. }\end{array}$ \\
\hline LA-212-102 & Determination of PH Direct Measurement \\
\hline LA-508-162 & Gamma Energy Analysis- the Genie System \\
\hline LA-508-052 & $\begin{array}{l}\text { Gamma Energy Analysis on the Canberra } \\
\text { Jupiter System }\end{array}$ \\
\hline LA-438-111 & $\begin{array}{l}\text { Determination of }{ }^{99} \mathrm{Tc} \text { by Solvent Extraction } \\
\text { and Liquid Scintillation Counting for } \\
\text { Effluents }\end{array}$ \\
\hline
\end{tabular}


Table 8-1. Analytical Procedures for FEMP Activities.

\begin{tabular}{|l|l|}
\hline Procedure Number* & \multicolumn{1}{|c|}{ Title } \\
\hline LA-505-241 & $\begin{array}{l}\text { Inductively Coupled Plasma-atomic Emission } \\
\text { Spectrometer <ICP-AES> Operations and } \\
\text { Analysis }\end{array}$ \\
\hline LA-508-121 & $\begin{array}{l}\text { Operation of the Beckman 255801 Liquid } \\
\text { Scintillation Counter } \\
\text { AEA using the Canberra Jupiter Systems } \\
\text { LA-508-101 }\end{array}$ \\
\hline LA-519-251 & $\begin{array}{l}\text { LUREX Visual Test } \\
\text { Compositing of PUREX Samples } \\
\text { LA-549-201 }\end{array}$ \\
LA-506-302 & $\begin{array}{l}\text { Total Alpha/Total Beta Mounting Procedure } \\
\text { Preparation of 125-m1 Sample Mounts for Low- } \\
\text { Level Gamma Energy Analysis } \\
\text { Loutine Sample Analysis with ICP Emissions } \\
\text { Spectrometer } \\
\text { Letermination of Uranium by Scintrex UA-3 } \\
\text { Laser Fluorometer }\end{array}$ \\
\hline
\end{tabular}

Legend: PUREX = Plutonium Uranium Extraction (Facility)

*Or approved alternative procedure 


\subsection{MONITORING AND REPORTING CRITERIA}

The effluent monitoring program encompasses all gaseous and liquid radioactive and nonradioactive effluent analyses performed for the WHC facilities requiring a FEMP.

The requirements for sampling and monitoring radioactive and nonradioactive gaseous effluents are contained in Section 2.0, "Air Quality," of WHC-CM-7-5. (WHC 1993b) and the results are to be reported annually by ES. At this time, ES only reports annually the nonradioactive air emissions $\left(\mathrm{NO}_{x}\right.$, $\mathrm{SO}_{2}$ emissions) that are registered with federal and state agencies.

Monitoring and reporting criteria are also in place for liquid effluent streams. Radioactive and nonradioactive liquid effluent monitoring requirements are identified in Section 8.0, "Water Quality" of WHC-CM-7-5 (WHC 1993b), and are to be reported annualiy. Those radioactive and nonradioactive streams that have a significant potential to become a dangerous waste must also be monitored and/or sampled in accordance with WHC-CM-7-5 (WHC 1993b), DOE Order 5400.1 (DOE 1988a) and DOE Order 5400.5 (DOE 1990) to ensure that no dangerous waste streams are released to the ground.

The EM organization manages and prepares the annual reports on radioactive effluent emissions from each Westinghouse Hanford facility. This report is prepared according to the guidelines/desk instructions set forth in Westinghouse Hanford-approved internal procedure WHC-IP-1066 (WHC 1994f). The QA requirements for the air emissions reporting are contained in the Quality Assurance Project Plan for Radioactive Airborne Emission Data Compilation and Reporting, WHC-EP-0528-1 (WHC 1994b). 
WHC-EP-0446-2

This page intentionally left blank. 


\subsection{DATA REDUCTION, VALIDATION, AND REPORTING}

\subsection{DATA REDUCTION AND DATA PACKAgE PREPARATION}

The iiquid and gaseous effluent monitoring record samples sent to the 222-S Laboratory shall be handled according to methods identified in WHC-SD-QAPP-003-1A, Quality Assurance Program Plan for Laboratory Analysis and Process Testing (WHC 1994C). The laboratories shall be responsible for preparing both a report summarizing the analysis results and a detailed data package including information necessary to perform data validation to the extent indicated by the minimum requirements.

\subsubsection{Gaseous Effluent Release Determinations}

Record sample gaseous effluent analytical data may include gross alpha and beta analyses, carbon-14 and tritium analyses, volatile isotope analyses, and specific radionuclide and nonradionuclide analyses as determined by the FEMP.. Each analysis is treated separately. Sample results are received from a Westinghouse Hanford-approved laboratory and included in the calculation of average concentration and total activity and summation for a calendar quarter. In addition, stack flow data obtained from the facility cognizant engineers are also included in the calculation. Calculations for annual reporting are. performed in accordance with WHC approved internal procedures.

\subsubsection{Liquid Effluent Release Determinations}

Record sample liquid effluent sampling data may include gross alpha and beta analyses and specific radionuclide and nonradionuclide analyses as determined by the FEMP. Proportioned liquid samples are collected on a daily shift or weekly basis and composited monthly for analysis. Sample results are received from a Westinghouse Hanford-approved laboratory from all streams for a single month and included in the annual report. Calculations of average concentration and total activity are derived from flow data and stream volumes provided by the facility cognizant engineers, as well as from the sample results from the laboratory, and are performed according to WHC approved internal procedures. For some storage facilities, such as the 340 waste Handling Facility, batch samples collected for less than 90-day radioactive low-level waste are the record samples identifying the inventory at risk.

\subsection{VALIDATION}

Completed data packages shall be verified by ES for radioactive effluents and validated by TQOC and/or the contracted laboratory. Alternative sources shall be used as directed by EM. Regardless of the source of validation services, validation requirements shall be defined by the project needs. 
When requested, validation reports for organic analysis shall be prepared documenting QC checks in any combination of the following areas, as recommenided in Laboratory Data Validation Functional Guidelines for Evaluating Organics Analysis (EPA 1988c):

- Data summary narrative

- Sample holding times

- Gas chromatograph/mass spectrometer tuning and mass calibration requirements

- Continuing calibration requirements

- Method blank sample requirements

- Surrogate recovery requirements

- Matrix spike/matrix spike duplicate requirements

- Internal standards performance requirements

- Target compound identification requirements

- Target compound quantitation requirements and reported detection limits

- Any tentatively identified compounds, library search, assessment, and quantitation requirements

- Overall data assessment requirements.

When requested, validation reports for inorganic analysis shall be prepared documenting QC checks in any combination of the following areas, as recommended in Laboratory Data Validation Functional Guidelines for Evaluating Inorganics Analysis (EPA 1988b):

- Data summary narrative

- Sample holding times

- Continuing calibration requirements

- Method blank sample requirements

- Inductively coupled plasma interference check sample requirements

- Laboratory control sample requirements

- Duplicate sample analysis

- Matrix spike sample requirements

- Atomic absorption $Q C$ requirements 
- Overall data assessment requirements

- Sample result verification.

Validation procedures for radionuclides and other types of analyses shall include requirements for $Q C$ checks with similar levels of detail.

The level of confidence in the data resulting from the radiological analyses shall be estimated by analyzing blanks and spiked pseudosamples (EPA-designated environmental measurement laboratory program) and by comparing the resulting concentration estimates to the known concentrations in those samples. Precision is calculated as standard deviation divided by the mean value and the level of precision that is required is determined by this project. The level of precision required for this project is minimum of $90 \%$ usable analytical data as identified in WHC-EP-0689, "Services Provided by the 222-S Laboratory for Regulatory Support" (Thomas 1993) or what is stipulated in the statement of work for other laboratories. When selecting the data to be considered, outliers shall be excluded from the data only after investigation confirms that an error has been made in the sample collection, preparation, measurement, or data analysis process. As new data are received, they shall be compared to earlier data.

\subsection{FINAL REVIEW AND RECORDS MANAGEMENT CONSIDERATIONS}

Validation reports and supporting analytical data packages will have a final technical review by ES before submittal to DOE and Ecology or inclusion in reports or technical memoranda. Validation reports, data packages, and review comments shall be retained as permanent project quality records at locations specified by the facility in accordance with WHC-CM-7-5 (WHC 1993b) and shall be defined in procurement documentation or work orders, as specified in the individual FEMPs. Records management practices shall comply with QR 17.0, "Quality Assurance Records" (WHC 1993d). 
WHC-EP-0446-2

This page intentionally left blank. 


\subsection{INTERNAL QUALITY CONTROL}

In general, analytical samples shall be subject to in-process $Q C$ measures in both the field facility and laboratory. Analytical samples both gaseous and liquid effluent will be subject to the QC protocol as discussed in these WHC documents:

- WHC-SD-CP-QAPP-002, Quality Assurance Project Plan for the Chemical Analysis of Highly Radioactive Mixed Waste Samples in Support of Environmental Activities on the Hanford Site (WHC 1993b)

- WHC-SD-CP-QAPP-003-1A, Quality Assurance Program Plan for Laboratory Analysis and Process Testing (WHC-1994C)

- WHC-EP-0689, Services Provided by the 222-S Laboratory for Regulatory Support (Thomas 1993)

- WHC-IP-1066, Effluent Monitoring Program (WHC-1994e)

- WHC-EP-0528-1, Quality Assurance Project Plan for Radioactive Airborne Emissions Data Compilation and Reporting (WHC-1994b) 
WHC-EP-0446-2

This page intentionally left blank. 


\subsection{SYSTEM AUDITS}

As noted in Section 2.4, audits shall be performed to verify the quality of operation of one or more elements of the total measurement system. In the sense intended by QAMS-005/80 (EPA 1983), system audits, involving a qualitative onsite evaluation of laboratories (or other organizational elements of the measurement system) for compliance with established QA program and procedure requirements. This also includes audits of individual facility sampling programs against those requirements in the FEMP.

System audits shall be performed by the appropriate organization (e.g., QA, Environmental Compliance Assurance) at least annually. Additional performance or system audits shall be performed if specifically required by individual FEMPs, as a consequence of corrective action requirements, or if requested by ES, QA, DOE-RL, EPA, or Ecology.

Any discrepancies that are observed during system audit surveillance activities and which cannot be immediately corrected to the satisfaction of the investigator, shall be documented. 
WHC-EP-0446-2

This page intentionally left blank. 


\subsection{PREVENTIVE MAINTENANCE}

Measurement and testing equipment used in the field and laboratory that directly affect the quality of the analytical data shall be subject to preventive maintenance measures that ensure minimization of measurement system downtime and ability to perform reliable measurements. Field equipment maintenance instructions shall be as defined by the approved procedures governing equipment use as listed in Appendix $A$ or the individual FEMP. Laboratories shall be responsible for performing or managing the maintenance of their analytical equipment; maintenance requirements, spare parts lists, and instructions shall be included in individual methods or in laboratory QA plans, subject to WHC review and approval as noted in Sections 3.3 . 
WHC-EP-0446-2

This page intentionally left blank. 


\subsection{DATA ASSESSMENT PROCEDURES}

Data from effluent sampling and monitoring shall be assessed as required according to procedures 1 isted in the appropriate statistical evaluation techniques that may be referenced herein. Analytical data shall be compiled by the laboratory and validated by WHC in compliance with

WHC-approved procedures, meeting the minimum requirements of Section 10.0. 
WHC-EP-0446-2

This page intentionally left blank. 


\subsection{CORRECTIVE ACTION}

Corrective action requests required as a result of surveillance or audit activity shall be documented and dispositioned as required by: $Q R$ 15.0, "Control of Nonconforming Items;" QI 15.1, "Nonconforming Item Reporting;" QI 15.2, "Nonconformance Report Processing;" QR 16.0, "Corrective Action;" QI 16.1, "Trend Analysis;" QI 16.2, "Corrective Action Request" (WHC 1993d); and WHC-CM-7-6, Environmental Compliance Verification Program Manual (WHC 1992b). 
WHC-EP-0446-2

This page intentionally left blank.

$15-2$ 


\subsection{QUALITY ASSURANCE REPORTS}

As stated in Sections 10.0 and 13.0, FEMP activities shall be regularly assessed by surveillance and auditing processes. Surveillance, nonconformance, audit, and corrective action documentation shail be considered QA records and shall be documented and dispositioned as stated in Section 15.0. Records management requirements applicable to subcontractors or participant contractors shall be defined in applicable procurement documents or work orders as noted in Section 4.2. 
WHC-EP-0446-2

This page intentionally left blank. 
WHC-EP-0446-2

\subsection{HUMAN FACTORS}

\subsection{EFFECTS OF HUMAN FACTORS}

Human factors affect the following activities associated with Hanford Site EM programs.

- Calibration of sampling and monitoring equipment

- Sample collection

- Transportation of samples to the analytical laboratories

- Proper storage and handling of samples in the laboratories

- Standardized testing of reagents used in the analysis performed on the samples received in the laboratory

- Proper training of laboratory staff to perform the analytical procedures

- Calibration of all equipment used in analysis of the samples

- Tracking of the samples through the laboratory

- Performance of the requested analytical procedures on the samples

- Entering laboratory results into an electronic database

- Maintaining quality of sample data in the database

- Performance of audits and compliance assessments.

\subsection{EFFECTS OF HUMAN FACTORS MINIMIZED BY PROCEDURES AND QUALITY ASSURANCE PLANS}

The effects of human factors on these activities are minimized by adherence to procedures such as those for:

- Sampling and Monitoring

- Equipment Calibration

- Chain-of-Custody

- Sample Handling

- Sample Analysis

- Data Handling

- Data Quality Assurance. 
The effects of human factors on activities associated with EM are also minimized by adherence to documents such as:

- Quality Assurance Program Plan for Radioactive Airborne Emissions Monitoring, WHC-EP-0536-1 (WHC 1993e)

- Quality Assurance Project Plans WHC-SD-WM-QAPP-011, Rev. 3 (WHC 1992), WHC-EP-0528-1 (WHC 1994b) 


\subsection{GLOSSARY}

Accuracy. Accuracy may be interpreted as the measure of bias in a system. Sampling accuracy is normally assessed by evaluating matrix spiked samples and reference samples.

Audit. Systematic checks to verify the quality of operation of one or more elements of the total measurement system. In this sense, audits may be of two types: (1) performance audits, in which quantitative data are independently obtained for comparison with data routinely obtained in a measurement system; or (2) system audits, involving a qualitative onsite evaluation of laboratories or other organizational elements of the measurement system for compliance with established QA program and procedure requirements. For effluent monitoring at the Hanford Site, performance audit requirements are fulfilled by periodic submittal of blind samples to the primary laboratory, or the analysis of split samples by an independent laboratory. System audit requirements are implemented through the use of standard surveillance procedures.

Blind Sample. Any type of sample routed to the primary laboratory for purposes of auditing performance relative to a particular sample matrix and analytical method. Blind samples are not specifically identified as such to the laboratory; they may be made from traceable standards, or may consist of sample material spiked with a known concentration of a known compound. See audit.

Comparability. An expression of the relative confidence with which one data set may be compared to another.

Completeness. A qualitative parameter expressing the percentage of measurements judged to be valid.

Contractual Quantitation Limit. The contractual quantitation limit (CQL) represents the lowest level of quantitation agreed on by the analytical laboratory and formally established in applicable contracts or work orders that the laboratory attests can be reliably achieved within contractually (or work order) established limits of precision and accuracy under routine laboratory operating conditions. The CQL is based on analytical experience and the data needs of individual projects; it represents the minimum acceptable standard against which analytical data will be judged.

Minimum Detectable Concentration. The smallest concentration of radioactive material in a sample that will yield a net count (above system background) that will be detected with a 95 percent confidence level.

$$
\left.D L=\left\{\left[(4.6)\left(S_{b}\right)\right]+(2.72 / T)\right]\right\} /\left[(E)(V)(2.22 E+06)(Y)\left(e^{-(k)(d t)}\right)\right]
$$


where:

$D L=$ The detection limit as defined above $(\mu \mathrm{Ci}$ per unit mass or volume)

$S_{b}=$ The standard deviation of the background counting rate (counts per minute)

$T=$ The sample count time in minutes

$E=$ The counting efficiency (counts per disintegration)

$V=$ The sample size (in units of mass or volume)

2.22 E+06 = Number of disintegrations per minute per microcurie

$Y=$ The fractional radiochemical yield (when applicable)

$\mathrm{e}=$ The base of natural logs (approximately 2.718)

$k$ = The radioactive decay constant for the particular radionuclide

$d t=$ The elapsed time between sample collection (or end of sample collection period) and the time of counting.

Deviation. A planned departure from established criteria that may be required as a result of unforeseen field situations or to correct ambiguities in procedures that may arise in practical applications.

Effective Dose Equivalent $\left(H_{F}\right.$ or EDE). An EDE is defined to be the summation of the products of the dose equivalent received by specified tissues of the body and a tissue-specific weighting factor. The sum is a riskequivalent value that can be used to estimate the health-effects risk of exposed individuals. The tissue-specific weighting factor represents the fraction of the total health risk resulting from uniform whole-body radiation that would be contributed by the particular tissue. The EDE includes the committed EDE from internal deposition of radionuclides and the EDE caused by penetrating radiation from sources external to the body. The EDE is expressed in units of rem (or sievert).

Effluent. Any treated or untreated air emission or liquid discharge at a DOE site or from a DOE facility. The term includes onsite discharge to the atmosphere, lagoons, ponds, cribs, injection wells, French drains, or ditches. The term does not include solid wastes stored or removed for disposal or wastes contained in retention basins or tanks before treatment and/or disposal.

Effluent Monitoring. Collection and analysis of samples or measurements of 1 iquid and gaseous effluents for the purpose of characterizing and quantifying contaminants, assessing radiation exposures of members of the public, providing a means to control effluents at or near the point of discharge, and demonstrating compliance with applicable standards and permit requirements. 


\section{Emission. See Effluent.}

Environmental Monitoring. Collection and analysis of samples or direct measurements (i.e., continuous monitoring) of environmental media. Environmental monitoring consists of two major activities: effluent monitoring and environmental surveillance.

Environmental Surveillance. Collection and analys is of samples or direct measurements of air, water, soil, foodstuff, biota, and other media from DOE sites and their environs for the purpose of determining compliance with applicable standards and permit requirements, assessing radiation exposures of members of the public and assessing the effects, if any, on the local environment.

Equipment Blanks. Pure deionized, distilled water washed through decontaminated sampling or testing equipment and placed in containers identical to those used for actual field samples. They are used to verify the adequacy of sampling equipment decontamination procedures and are normally collected as frequently as field duplicate samples.

Nonconformance. A nonconformance is a deficiency in characteristic, documentation, or procedure that renders the qual ity of material, equipment, services, or activities unacceptable or indeterminate. When the deficiency is minor, does not effect a permanent or significant change in quality if it is not corrected, and can be brought into conformance with immediate corrective action, it shall not be categorized as a nonconformance. However, if the nature of the condition is such that it cannot be immediately and satisfactorily corrected, it shall be documented in compliance with approved procedures and brought to the attention of management for disposition and appropriate corrective action.

Precision. A measure of the repeatability or reproducibility of specific measurements under a given set of conditions. Specifically, it is a quantitative measure of the variability of a group of measurements compared to their average value. Precision is normally expressed in terms of standard deviation, but may also be expressed as the coefficient of variation (i.e., relative standard deviation) and range (i.e., maximum value minus minimum value). Precision is assessed by means of duplicate/replicate sample analysis.

Proportional Sampling or Monitoring. For continuous airborne effluents, the ratio of the sample flowrate (e.g., the flow through the filter) to the discharge flowrate is constant within acceptable limits. For continuous liquid effluents, the ratio of the sample volume to the discharge volume is constant. For batch releases, the ratio of the sample volume to batch volume is constant from batch to batch. (This applies only to the final volumetric composition of the record sample as analyzed by the laboratory.)

Quality Assurance. The total integrated quality planning, QC, quality assessment, and corrective action activities that collectively ensure that data from monitoring and analys is meet all end user requirements and/or the intended end use of the data. 
Quality Assurance Project Plan. An orderly assembly of management policies, project objectives, methods, and procedures that define how data of known quality will be produced for a particular project, investigation, or monitoring program.

Quality Control. For the purposes of effluent monitoring, QC refers to the routine application of procedures and defined methods to the performance of sampling, measurement, and analytical processes.

Record Sample. A representative sample collected in a sampling system for laboratory analysis used as a basis for reporting to the DOE, facility operations, and safety the amounts of contaminants released to the environment.

Reference Samples. A type of laboratory QC sample prepared from an independent, traceable standard at a concentration other than that used for analytical equipment calibration, but within the calibration range. Reference samples are required for every analytical batch or every 20 samples, whichever is greater.

Replicate Sample. Replicate samples are two or more aliquots removed from the same sample container in the laboratory and analyzed independently.

Representativeness. May be interpreted as the degree to which data accurately and precisely represent a characteristic of a population parameter, variations at a sampling point, or an environmental condition. Representativeness is a qualitative parameter that is most concerned with the proper design of a sampling program. air.

Sample. A physical specimen of air, water, or particles filtered from

Sampling Schedule. A description of routine sampling necessary to support the effluent monitoring program. Sampling schedules specify the effluent, location, size, type, and frequency of samples to be collected.

Sampling System. Instrumentation and equipment that remove a part of a liquid or airborne waste stream for subsequent quantitative determination of a stream parameter. The sampling system generally employs such devices as filters, other sample collection media, or effluent traps of some kind. A continuous sampling system removes a part. of the stream continuously except during sample change, maintenance, repair, or other necessary outages. A grab sampling system instantaneously removes a part of the stream or removes a part of the stream over a period of time.

Split Sample. A split sample is produced by homogenizing a field sample and separating the sample material into two equal aliquots. Field split samples are usually routed to separate laboratories for independent analysis, generally to audit. the performance of the primary laboratory relative to a particular sample matrix and analytical method. In the laboratory, samples are generally split to create matrix spike samples. 
Trip Blanks. A type of field QC sample consisting of pure, deionized, distilled water in a clean, sealed sample container. Trip blanks accompany each batch of containers shipped to the sampling site and are returned unopened to the laboratory. They are used to identify any possible contamination originating from container preparation methods, shipment, handling, storage, or site conditions.

Validation. A systematic process of reviewing a body of data against a set of criteria to ensure that the data are acceptable for their intended use. Validation methods may include review of verification activities (i.e., QC program), editing, screening, cross checking, historical trending, and technical review.

Verification. Verification refers to the process of determining whether procedures, processes, data, or documentation conform to specified requirements. Verification activities may include inspections, audits, surveillances, or technical review. 
WHC-EP-0446-2

This page intentionally left blank. 


\subsection{REFERENCES}

APHA, 1985, Standard Methods for the Examination of Water and Wastewater, 16th ed., American Public Health Association, American Water Works Association, and Water Pollution Control Federation, Washington, D.C.

Diediker, L. P., 1993, Analytical Requirements for FY-94 Liquid Effluent and Air Emission Samples, Internal Memo 88420-93-135b to R. P. Marshal1, December 21, 1993, Westinghouse Hanford Company, Richland, Washington.

DOE, 1981, Environmental Protection, Safety, and Health Protection Information Reporting Requirements, DOE Order 5484.1, U.S. Department of Energy, Washington, D.C.

DOE, 1982, Environmental Protection, Safety, and Health Protection Program for $R L$, DOE Order 5480.1, U.S. Department of Energy, Washington, D.C.

DOE, 1988a, General Environmental Protection Program, DOE Order 5400.1, U.S. Department of Energy, Washington, D.C.

DOE, 1988b, Radiation Protection for Occupational Workers, DOE Order 5480.1 , U.S. Department of Energy, Washington, D.C.

DOE 1989a, Comprehensive Environmental Response Compensation and Liability Act Requirements, DOE Order 5400.4, U.S. Department of Energy, Washington, D.C.

DOE, 1989b, Hazardous and Radioactive Mixed Waste Program, DOE Order 5400.3, U.S. Department of Energy, Washington, D.C.

DOE, 1990, Radiation Protection of the Public and the Environment, DOE Order 5400.5, U.S. Department of Energy, Washington, D.C.

DOE, 1991, Quality Assurance, DOE Order 5700.6C, U.S. Department of Energy, Washington D.C.

DOE-RL, 1989, Environmenta7 Protection Implementation P7an, DOE-RL 89-18, U.S. Department of Energy Richland Operations Office, Richland, Washington.

DOE-RL, 1991, Environmenta7 Monitoring P7an, DOE/RL-91-50, U.S. Department of Energy Richland Operations Office, Richland, Washington.

DOE-RL, 1993, Hanford Site Environmental Protection Plan (DOE/Quality), DOE/RL-93-97, U.S. Department of Energy Richland Field Office, Richland, Washington.

Ecology, 1983, Chemical Testing Methods for Complying with the State of Washington Dangerous Waste Regulations, 83-13, Washington State Department of Ecology, Olympia, Washington.

EPA, 1972, Handbook for Analytical Quality Control in Water and Wastewater Laboratories, U.S. Environmental Protection Agency, Washington, D.C. 
EPA, 1977, Handbook for Analytical Quality Control in Radioanalytical Laboratories, EPA-600/7-77/088, U.S. Environmental Protection Agency, Washington, D.C.

EPA, 1979, Methods for Chemical Analysis of Water and Wastes, EPA-600/4-79-020, U.S. Environmental Protection Agency/Environmental Monitoring and Support Laboratory, Cincinnati, Ohio.

EPA, 1982, Prescribed Procedures for the Measurement of Radioactivity in Drinking Water, EPA 600/4-80-032, U.S. Environmental Protection Agency/Office of Exploratory Research, Washington, D.C.

EPA, 1983, Interim Guidelines and Specifications for Preparation of Quality Assurance Project Plans, QAMS-005/80, U.S. Environmental Protection Agency/Office of Exploratory Research, Washington, D.C.

EPA, 1984, Eastern Environmental Radiation Facility (EERF) Radiochemistry Procedures Manual, EPA 520/5-84-006, U.S. Environmental Protection Agency, Washington, D.C.

EPA, 1986, RCRA Groundwater Monitoring Technical Enforcement Guidance Document, Office of Waste Programs Enforcement, Office of Solid Waste and Emergency Response, U.S. Environmental Protection Agency, Washington, D.C.

EPA, 1988a, Comprehensive Environmental Response, Compensation and Liability Act of 1980, Title 40, Code of Federal Regulations, Part 302, U.S. Environmental Protection Agency, Washington, D.C.

EPA, 1988b, Laboratory Data Validation Functional Guidelines for Evaluating Inorganics Analyses, Hazardous Site Evaluation Division, U.S. Environmental Protection Agency, Washington, D.C.

EPA, 1988c, Laboratory Data Validation Functional Guidelines for Evaluating Organics Analyses, Hazardous Site Evaluation Division, U.S. Environmental Protection Agency, Washington, D.C.

EPA, 1988d, Standards for Owners and Operators of Hazardous Waste Treatment, Storage, and Disposal Facilities, Title 40, Code of Federal Regulations, Part. 264, U.S. Environmental Protection Agency, Washington, D.C.

EPA, 1989a, "Hazardous Waste Management System; Testing and Monitoring Activities (Proposed Rule);" Federal Register, Vol. 54, No. 13, pp. 3212-3228, U.S. Environmental Protection Agency, Washington, D.C.

EPA, 1989b, Statistical Analysis of Ground-Water Monitoring Data at RCRA Facilities - Interim Final Guidance, Office of Solid Waste/Waste Management Division, U.S. Environmental Protection Agency, Washington, D.C.

EPA, 1992a, National Emission Standards for Hazardous Air Pollutants, Title 40, Code of Federal Regulations, Part 61, Subpart H, U.S. Environmental Protection Agency, Washington D.C. 
EPA, 1992b, Quality Assurance Methods, Title 40, Code of Federal Regulations, Part 61, Appendix B, Method 114, U.S. Environmental Protection Agency, Washington, D.C.

EPA, 1992c, Test Methods for Evaluating Solid Wastes, SW-846-1, Third Edition, Office of Solid Waste and Emergency Response, U.S. Environmental Protection Agency, Washington, D.C.

Perry, J. K., 1993, Statement of Work for Services Provided by Pacific Northwest Laboratory's Analytical Chemistry Laboratory for the 340 Facility, Westinghouse Hanford Company, Richland, Washington.

PNL, 1991a, Analytical Chemistry Laboratory Manual, PNL-597, Pacific Northwest Laboratory, Richland, Washington.

PNL, 1991b, Quality Assurance (QA) Program, PNA-MA-70, Pacific Northwest Laboratory, Richland, Washington.

PNL, 1991c, QA Plan for Activities Conducted by the Analytical Chemistry Laboratory $(A C L)$, MCS-033, Pacific Northwest Laboratory, Richland, Washington.

Resource Conservation and Recovery Act of 1976, as amended, 42 USC 6901, et seq.

Seamens, M., 1993, Letter of Instruction--Work Order ED4232, (internal memo 9359236 to M. W. Urie, November 15, 1993, Pacific Northwest Laboratory, Richland, Washington.

Thoelke, T. M., 1993, Letter of Instruction - Work Order ED4232, (internal memo 9359235 to M. W. Urie, November 15, 1993), Pacific Northwest Laboratory, Richland, Washington.

Thomas, S. P. 1993, Services Provided by the 222-S Laboratory for Regulatory Support, WHC-EP-0689, Westinghouse Hanford Company, Richland, Washington.

WHC, 1991, K Basin Process Standard No. D-403, Westinghouse Hanford Company, Richland, Washington.

WHC, 1992, Liquid Effluent Sampling Quality Assurance Project Plan, WHC-SD-WM-QAPP-011, Rev. 3, Westinghouse Hanford Company, Richland, Washington.

WHC, 1992a, A Guide for Preparing Hanford Site Facility Effluent Monitoring PIans, WHC-EP-0438-1, Westinghouse Hanford Company, Richland, Washington

WHC, 1992b, Environmental Compliance Verification Program Manual, WHC-CM-7-6, Westinghouse Hanford Company, Richland, Washington.

WHC, 1992c, Operational Environmental Monitoring Program Quality Assurance Project P7an, WHC-EP-0538, Westinghouse Hanford Company, Richland, Washington. 
WHC, 1993a, 300 Area Process Sewer Sampling Analysis Plan, WHC-SD-PNL-001, Rev. 0, Westinghouse Hanford Company, Richland, Washington.

WHC, 1993b, Environmental Compliance Manual, WHC-CM-7-5, Westinghouse Hanford Company, Rịchland, Washington.

WHC, 1993c, Health Physics Procedures Manual, WHC-IP-0718, Westinghouse Hanford Company, Richland, Washington.

WHC, 1993d, Quality Assurance Manual, WHC-CM-4-2, Westinghouse Hanford Company, Richl and, Washington.

WHC, 1993e, Quality Assurance Program Plan for Radioactive Airborne Emissions Monitoring, WHC-EP-0536-1, Westinghouse Hanford Company, Richland, Washington.

WHC, 1993f, Quality Assurance Project Plan for the Chemical Analysis of Highly Radioactive Mixed Waste Samples in Support of Environment Activities on the Hanford Site, WHC-SD-CP-QAPP-002, Westinghouse Hanford Company, Richl and, Washington.

WHC, 1993g, Standard Engineering Practices, WHC-CM-6-1, Westinghouse Hanford Company, Richland, Washington.

WHC, 1994, Effluent Monitoring Program, WHC-IP-1066, Westinghouse Hanford Company, Richland, Washington.

WHC, 1994a, FFTF Operations Operating Procedures, SN-23.13.3, Operation of the Process Sewer, Westinghouse Hanford Company, Richland, Washington.

WHC, 1994b, Quality Assurance Project Plan for Radioactive Airborne Emissions Data Compilation and Reporting, WHC-EP-0528-1, Westinghouse Hanford Company, Richl and, Washington.

WHC, 1994c, Quality Assurance Program P7an for Laboratory Analysis and Process Testing, WHC-SD-CP-QAPP-003-1A, Westinghouse Hanford Company, Richland, Washington.

WHC, 1994d, Document Control and Records Management Manual, WHC-CM-3-5, Westinghouse Hanford Company, Richland, Washington.

WHC, 1994e, Operational Environmental Monitoring Manual, WHC-CM-7-4, Westinghouse Hanford Company, Richland, Washington.

WHC, 1994f, Management Requirements and Procedures, WHC-CM-1-3, Westinghouse Hanford Company, Richland, Washington. 
WHC-EP-0446-2

APPENDIX A

A-1 
WHC-EP-0446-2

This page intentionally left blank. 
APPENDIX A

Table A-1. Supporting Procedures for Facility Effluent Monitoring Plan Activities. (7 sheets)

\begin{tabular}{|c|c|c|c|}
\hline Procedure & Procedure Number & Title & Facility \\
\hline \multirow[t]{9}{*}{$\begin{array}{l}\text { Chain-of-Custody, } \\
\text { Sample Packaging, } \\
\text { and Shipping }\end{array}$} & TO-080-060 & $\begin{array}{l}\text { Chain of Custody } \\
\text { Health Physics Procedures } \\
\text { Manual } \\
\text { Chain-of-Custody Process } \\
\text { sampler }\end{array}$ & $\begin{array}{l}\text { 242-A } \\
\text { Evaporator }\end{array}$ \\
\hline & $\begin{array}{l}\text { WHC-IP-0568 } \\
\text { SWUL-A-020 }\end{array}$ & $\begin{array}{l}\text { Chain of Custody } \\
200 \text { Area Steam \& Water } \\
\text { Utilities Operations } \\
\text { Administration Procedures }\end{array}$ & $\begin{array}{l}\text { 284E/W } \\
\text { Powerhouses }\end{array}$ \\
\hline & $\begin{array}{l}\text { WHC-CM-5-6 } \\
\text { BO-080-008 }\end{array}$ & $\begin{array}{l}\text { B Plant Operations } \\
\text { Administration } \\
\text { Sample Truck Transport } \\
\text { and Accountability at } \\
\text { B Plant }\end{array}$ & B Plant \\
\hline & SW-025-006 & $\begin{array}{l}\text { Package and Transfer of } \\
\text { Radioactive Liquid Waste } \\
\text { Samples }\end{array}$ & $\begin{array}{l}340 \text { Waste } \\
\text { Handl ing }\end{array}$ \\
\hline & $\begin{array}{l}\text { Laboratory } \\
\text { Procedure Control } \\
\text { Book (No Number) }\end{array}$ & $\begin{array}{l}\text { Analytical Chemistry } \\
\text { Services Laboratories } \\
\text { Operat ing Instructions } \\
\text { Manual }\end{array}$ & $\begin{array}{l}222-S \\
\text { Laboratory }\end{array}$ \\
\hline & POP-Z0-102-010 & Sample 2904-ZA & PFP \\
\hline & $P 0-080-0315$ & $\begin{array}{l}\text { PUREX Sample Chain-of- } \\
\text { Custody }\end{array}$ & PUREX, U03 \\
\hline & $\begin{array}{l}\text { Desk Instruction } \\
91-X-005\end{array}$ & Chain of Custody & FFTF \\
\hline & $\begin{array}{l}\text { HRWC-03 } \\
\text { HRWC-06 } \\
\text { HRWC-07 } \\
\text { HRWC-08 }\end{array}$ & $\begin{array}{l}\text { Waste } \\
\text { Hazardous Waste } \\
\text { Mixed Waste } \\
\text { Radioactive Waste }\end{array}$ & $\mathrm{KE} / \mathrm{KW}$ Basins \\
\hline $\begin{array}{l}\text { Sampling } \\
\text { Monitoring } \\
\text { Airborne }\end{array}$ & $\begin{array}{l}\text { WHC-IP-0718 } \\
\text { Section ER-04 }\end{array}$ & $\begin{array}{l}\text { Health Physics Procedures } \\
\text { Manual } \\
\text { Effluent Exhaust CAM } \\
\text { Alarm Response }\end{array}$ & $\begin{array}{l}\text { All } \\
\text { Facilities }\end{array}$ \\
\hline
\end{tabular}


Table A-1. Supporting Procedures for Facility Effluent Monitoring Plan Activities. (7 sheets)

\begin{tabular}{|c|c|c|c|}
\hline Procedure & Procedure Number & Title & Facility \\
\hline $\begin{array}{l}\text { Sampling } \\
\text { Monitoring } \\
\text { airborne } \\
\text { (continued) }\end{array}$ & $\begin{array}{l}\text { Section } 3.1 .1 \\
\text { Section } 3.2 .1 \\
\text { Section } 3.3 .1 \\
\text { Section } 3.3 .2 \\
\text { Section } 3.3 .3 \\
\text { WHC-IP-0718 } \\
\text { (Appendix I) } \\
\text { Section } 4.2 \\
\text { Section } 5.3\end{array}$ & $\begin{array}{l}\text { Material Release Surveys } \\
\text { Radioactive Material } \\
\text { Shipment and Receipt } \\
\text { Exchange } \\
\text { Air Sampling } \\
\text { Gaseous Effluent } \\
\text { Monitoring System } \\
\text { Inspection and Sample } \\
\text { Exchange } \\
\text { Automated Bar Coding of } \\
\text { Air Samples at Hanford } \\
\text { (ABCASH) } \\
\text { Continuous Air Monitoring } \\
\text { Air Sample Envelopes and } \\
\text { Counter Log Sheets }\end{array}$ & $\begin{array}{l}\text { All } \\
\text { Facilities }\end{array}$ \\
\hline $\begin{array}{l}\text { Sampling } \\
\text { Monitoring liquid }\end{array}$ & $\begin{array}{l}\text { WHC-CM-5-8 } \\
\text { FSS-Z-080-00003 }\end{array}$ & $\begin{array}{l}\text { PFP Administration Manual } \\
\text { 291-Z Sump and Z-20 Crib } \\
\text { Rout ine Sample Schedule }\end{array}$ & PFP \\
\hline
\end{tabular}


Table A-1. Supporting Procedures for Facility Effluent Monitoring Plan Activities. (7 sheets)

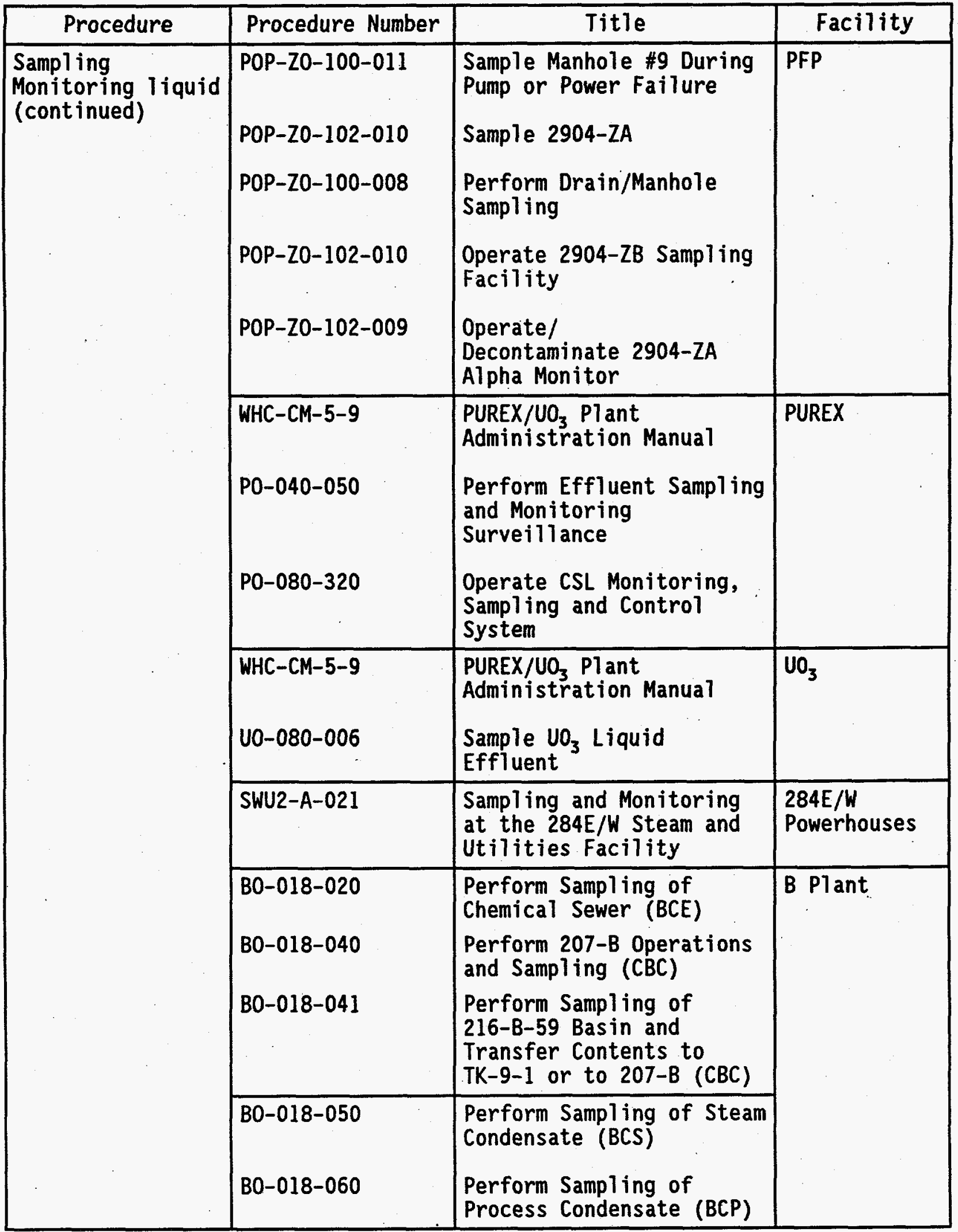


Table A-1. Supporting Procedures for Facility Effluent Monitoring Plan Activities. (7 sheets)

\begin{tabular}{|c|c|c|c|}
\hline Procedure & Procedure Number & Title & Facility \\
\hline \multirow[t]{4}{*}{$\begin{array}{l}\text { Sampling } \\
\text { Monitoring liquid } \\
\text { (continued) }\end{array}$} & T0-080-060 & $\begin{array}{l}\text { Sample Cooling Water from } \\
242-A \text { Evaporator via } \\
\text { Receiver Tank RC-2 } \\
\text { Chain of Custody Process } \\
\text { Sampler }\end{array}$ & $\begin{array}{l}242-A \\
\text { Evaporator }\end{array}$ \\
\hline & SW-080-001 & $\begin{array}{l}\text { Sample Vault Tanks } \\
\text { Radioactive Liquid Waste }\end{array}$ & $\begin{array}{l}340 \text { Waste } \\
\text { Handl ing }\end{array}$ \\
\hline & $\begin{array}{l}\text { WHC-IP-0718 } \\
\text { Sect ion } 4.5 C \\
\text { (WHC 1993C) }\end{array}$ & $\begin{array}{l}\text { Operation of the } 400 \text { Area } \\
\text { Effluent Monitoring } \\
\text { System }\end{array}$ & $\begin{array}{l}\text { Al1 } 400 \text { Area } \\
\text { gaseous } \\
\text { emission } \\
\text { sampling } \\
\text { systems }\end{array}$ \\
\hline & $\begin{array}{l}\text { WHC-IP-0718 } \\
\text { Section } 4.6 C\end{array}$ & $\begin{array}{l}\text { Operation of Tri-Carb } \\
\text { Liquid Scintillation } \\
\text { Counter }\end{array}$ & $\begin{array}{l}\text { All } \\
\text { West inghouse } \\
\text { Hanford } \\
\text { Stacks }(100, \\
200,300, \\
400 \text { Areas) }\end{array}$ \\
\hline \multirow[t]{5}{*}{ Calibration } & 2B18002 & P.M. & \multirow[t]{5}{*}{ B Plant } \\
\hline & $05-B M-050$ & $\begin{array}{l}\text { B Plant CO Monitor } \\
\text { Calibration }\end{array}$ & \\
\hline & 2B18010 & $\begin{array}{l}\text { B Plant Flow Indicator } \\
\text { Inspection, Cleaning, and } \\
\text { Functional Test }\end{array}$ & \\
\hline & $2 \mathrm{~B} 18015$ & $\begin{array}{l}\text { B P1 ant } 18-2 \text { IX Bedford } \\
\text { Monitor Calibration }\end{array}$ & \\
\hline & 2B18019 & $\begin{array}{l}\text { 291-B Turbine Building } \\
\text { Calibrations }\end{array}$ & \\
\hline
\end{tabular}


Table A-1. Supporting. Procedures for Facility Effluent Monitoring Plan Activities. (7 sheets)

\begin{tabular}{|c|c|c|c|}
\hline Procedure & Procedure Number & Title & Facility \\
\hline \multirow[t]{8}{*}{$\begin{array}{l}\text { Calibration } \\
\text { (continued) }\end{array}$} & $\begin{array}{l}2 \mathrm{~B} 18023 \\
2 \mathrm{~B} 18024 \\
2 \mathrm{~B} 18025 \\
2 \mathrm{~B} 18030 / \\
05-\mathrm{BM}-045 \\
\text { PSCP-5-003 }\end{array}$ & $\begin{array}{l}\text { Calibration at 221-BA/BG } \\
\text { Bailey System Filter and } \\
\text { Ribbon Inspection-271-B } \\
\text { and 22l-B } \\
\text { Functional Test of } \\
\text { B Plant Bailey } \\
\text { "Network } 90 " \text { "Analog Meter } \\
\text { Module AMM02 } \\
\text { G-M Area Monitoring } \\
\text { System Model 855/856 } \\
\text { Breathing Air Analyzer } \\
\text { Calibration at 225-B, } \\
\text { Radiation Monitor }\end{array}$ & B Plant \\
\hline & $\begin{array}{l}\text { PSCP-4-188 } \\
\text { PSCP-4-189 }\end{array}$ & $\begin{array}{l}\text { Yokogawa (YEW) Recorder } \\
\text { Mode1 ERI06-A } \\
\text { Lear Siegler RN7A/RN7AN } \\
\text { Opacity Monitor/ } \\
\text { Indicator }\end{array}$ & $\begin{array}{l}284 E / W \\
\text { Powerhouses }\end{array}$ \\
\hline & $\begin{array}{l}\text { PSCP-7-041 } \\
\text { PSCP-4-218 }\end{array}$ & $\begin{array}{l}\text { NOx Monitor Calibration } \\
\text { Interscan NOx Multipoint } \\
\text { Continuous Monitoring } \\
\text { System (MCMS) }\end{array}$ & PUREX, $\mathrm{UO}_{3}$ \\
\hline & PSCP-3-087 & $\begin{array}{l}\text { Eberline PING Monitoring } \\
\text { System/PUREX Main Stack } \\
\text { Calibration }\end{array}$ & \multirow[t]{5}{*}{ PUREX } \\
\hline & $\begin{array}{l}\text { CSL Work package } \\
\text { PSCP-3-054 }\end{array}$ & $\begin{array}{l}\text { Liquid Effluent On-1ine } \\
\text { Alpha Monitor for PUREX } \\
\text { PUREX Main Stack CPRM } \\
\text { Beta and Channel } \\
\text { Cal ibration }\end{array}$ & \\
\hline & PSCP-3-083 & $\begin{array}{l}\text { PUREX Modified Effluent } \\
\text { CAM Eberl ine Alpha-5A for } \\
\text { Detection of }{ }^{239} \mathrm{Pu}\end{array}$ & \\
\hline & PSCP-1-044 & $\begin{array}{l}\text { Kurz } 142 / 151 \mathrm{KM} \\
\text { Calibration }\end{array}$ & \\
\hline & PSCP-1-045 & $\begin{array}{l}\text { Kurz Linear Mass Flow } \\
\text { Meter Series } 505 \text { at PUREX }\end{array}$ & \\
\hline
\end{tabular}


Table A-1. Supporting Procedures for Facility Effluent Monitoring Plan Activities. ( 7 sheets)

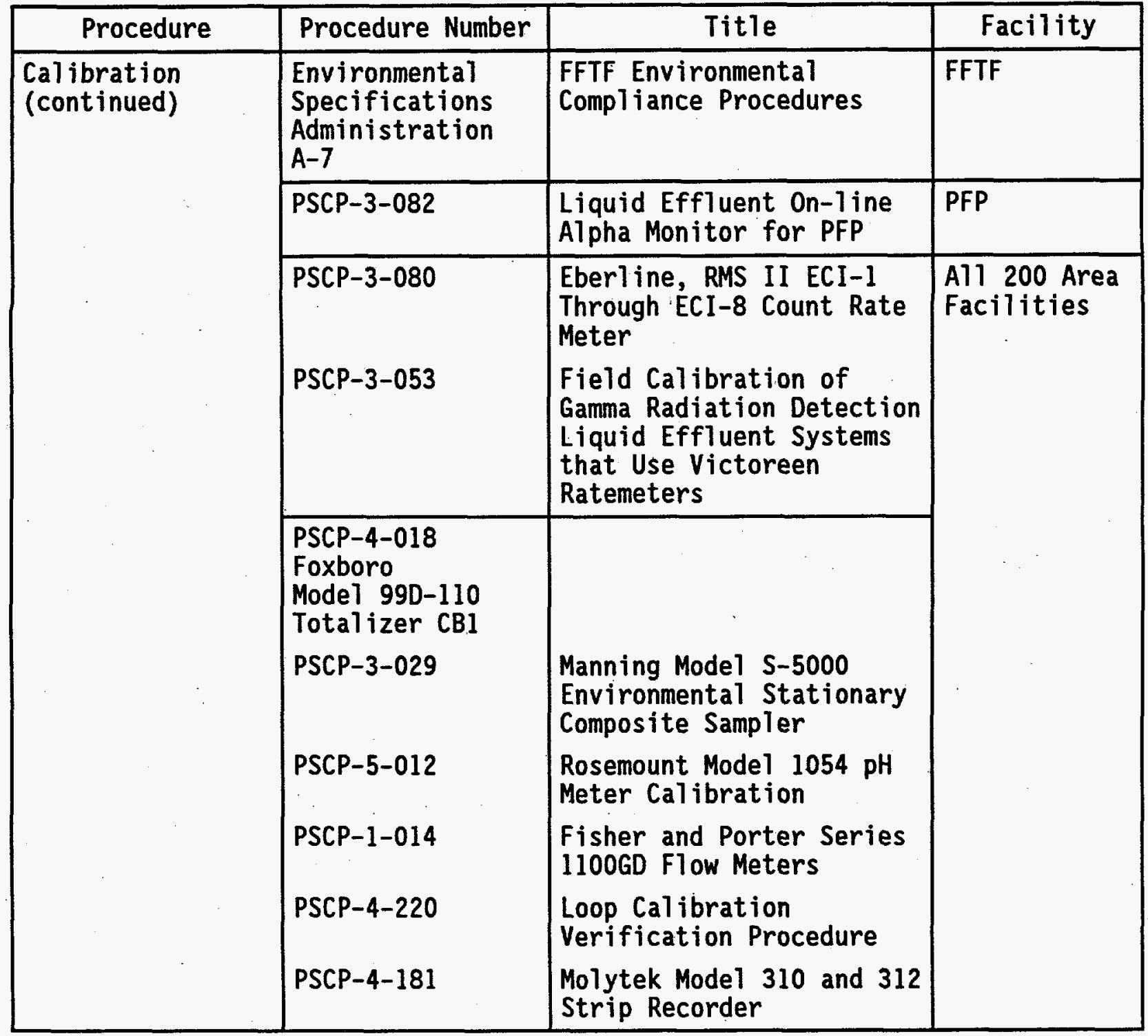


Table A-1. Supporting Procedures for Facility Effluent Monitoring Plan Activities. (7 sheets)

\begin{tabular}{|c|c|c|c|}
\hline Procedure & Procedure Number & Title & Facility \\
\hline $\begin{array}{l}\text { Calibration } \\
\text { (continued) }\end{array}$ & $\begin{array}{l}\text { PSCP-3-040 } \\
\text { PSCP-3-046/065 } \\
\text { PSCP-3-060 } \\
\text { PSCP-3-064 } \\
\text { PSCP-3-076 }\end{array}$ & $\begin{array}{l}\text { Ortec Model 406A Single } \\
\text { Channel Analyzer } \\
\text { Ortec Mode1 } 485 \text {, } \\
\text { Model } 541 \text {, Ampl ifier and } \\
\text { Rate Meter } \\
\text { Ortec Model } 773 \text { and } \\
773 \mathrm{H} \text { Timer/Counter Test } \\
\text { Procedure } \\
\text { Tennelec Count Ratemeter } \\
\text { Models TC595/TC595M } \\
\text { Calibration } \\
\text { Victoreen Model } 842 \\
\text { Series Electronic } \\
\text { Calibration }\end{array}$ & $\begin{array}{l}\text { A11 } 200 \text { Area } \\
\text { Facilities }\end{array}$ \\
\hline
\end{tabular}

Legend: $\quad$ ABCASH = Automated Bar Coding of Air Samples at Hanford

FFTF = Fast Flux Test Facility

MCMS = Multipoint Continuous Monitoring System

PFP $=$ Plutonium Finishing Plant

PUREX = Plutonium Uranium Extraction (Facility) 
WHC-EP-0446-2

This page intentionally left blank. 


\section{DISTRIBUTION}

Number of Copies

ONSITE

U.S. Department of Energy, Richland Operations Office

J. D. Bauer

A5-15

G. M. Bell

A5-52

R. F. Brich

A5-55

R. G. Holt

A5-15

E. B. Dagan

A5-19

S. D. Stites

A5-19

Public Reading Room

H2-53

Pacific Northwest Laboratory

W. J. Bjorklund

P7-68

T. D. Chikalla

P7-75

G. R. Hoenes

P7-78

R. E. Jaquish

K1-30

D. L. Klages

P7-68

R. K. Woodruff

K6-13

Technical Files

$\mathrm{K} 1-11$

Westinghouse Hanford Company

D. Alison

R1-52

D. D. Bachand

L. D. Berneski

D. J. Carrel1

G. M. Crumme1

N. R. Dah1

L. P. Diediker

J. J. Dorian

B. G. Erl andson

T. P. Frazier (20)

D. W. Fritz

L. A. Garner

R1-52

L6-04

H6-22

R1-51

N2-04

T1-30

H6-30

H6-20

T1-30

H6-22

R2-86

J. L. Geiger

R3-01

E. M. Greager

H6-30

D. L. Halgren

S6-70

K. A. Hadley

J. S. Hunacek

R3-56

$\mathrm{XO}-41$

D. R. Herman

S2-12

D. L. Johnson

S6-19

R. E. Johnson

T1-30

G. H. Lavey

T6-12

J. Lohrasbi

S6-19

H. K. Meznarich

T6-16

J. H. Mizner

T3-28 


\section{DISTRIBUTION (continued)}

Number of Copies

ONSITE

Westinghouse Hanford Company (continued)

K. A. Peterson

H6-30

D. W. Ranade

B2-16

P. J. Sullivan

L. W. Vance

T5-54

D. D. Volkman

H4-16

G. J. Warwick

H4-25

D. J. Watson

C. D. Woll am

$\mathrm{T} 6-12$

$\mathrm{X0}-41$

Central Files

S6-17

Document Processing and Distribution (2)

O.S.T.I. (2)

L8-15

L8-07 